\title{
Partisan Bias in Economic News: Evidence on the Agenda-Setting Behavior of U.S. Newspapers ${ }^{1}$
}

\author{
Valentino Larcinese \\ Department of Government and Sticerd \\ London School of Economics
}

Riccardo Puglisi

ECARES

Université Libre de Bruxelles

James M. Snyder, Jr.

Department of Political Science and Economics

Massachusetts Institute of Technology

PEPP/27

March 2008

Political Economy and Public Policy Series

The Suntory Centre

Suntory and Toyota International Centres for

Economics and Related Disciplines

London School of Economics and Political Science

Houghton Street

London WC2A 2AE

\footnotetext{
${ }^{1}$ We thank Radu Ban, Bob Erikson, Raphael Franck, Chap Lawson, Gabe Lenz, Andrea Prat, Carlo Rosa, Jesse Shapiro, Michiko Ueda and seminar participants at Bristol, Cambridge, Columbia, Durham, Rome (Ente Einaudi), LSE, MIT, Milan, Suffolk, the World Meeting of the Public Choice Societies (Amsterdam) for helpful comments. We also give a very special thanks to Michael Naber for making the data collection possible.
} 


\begin{abstract}
We study the agenda-setting political behavior of a large sample of U.S. newspapers during the last decade, and the behavior of smaller samples for longer time periods. Our purpose is to examine the intensity of coverage of economic issues as a function of the underlying economic conditions and the political affiliation of the incumbent president, focusing on unemployment, inflation, the federal budget and the trade deficit. We investigate whether there is any significant correlation between the endorsement policy of newspapers, and the differential coverage of bad/good economic news as a function of the president's political affiliation. We find evidence that newspapers with proDemocratic endorsement pattern systematically give more coverage to high unemployment when the incumbent president is a Republican than when the president is Democratic, compared to newspapers with pro-Republican endorsement pattern. This result is not driven by the partisanship of readers. There is on the contrary no evidence of a partisan bias - or at least of a bias that is correlated with the endorsement policy - for stories on inflation, budget deficit or trade deficit.
\end{abstract}

(C) The authors. All rights reserved. Short sections of text, not to exceed two paragraphs, may be quoted without explicit permission provided that full credit, including $\odot$ notice, is given to the source 


\section{Introduction}

News provided by the mass media are the most important source of information on public affairs in modern democratic societies. Hence, media outlets play a fundamental role in keeping the public informed on the decisions of their political representatives as well as on issues and events that are relevant to public decision-making. Time and space available being limited, journalists exercise a considerable degree of discretion on the topics covered and the tone of the reports. It would therefore not be surprising if the political views of individual journalists were reflected in news reported in the mass media.

One of the most important claims about news in the mass media is the agenda-setting hypothesis. The idea is that editors and journalists have a large degree of freedom in deciding what is newsworthy and what is not, and these choices influence the perception of citizens about which issues are relevant and to what extent. Cohen [1963] stated it eloquently: the press "may not be successful much of the time in telling people what to think, but it is stunningly successful in telling its readers what to think about." The exploitation of agenda-setting power is potentially one of the most harmful behaviors by news media, especially if they use this power to suppress information. The reason is that it is difficult for consumers to distinguish the scenario "I did not see any news about X today because nothing important happened regarding X" from the scenario "I did not see any news about $\mathrm{X}$ today because, although something important happened, the media decided not to publish it". Theoretical models by Anderson and McLaren [2005], Bernhardt, Krasa and Polborn [2006], Besley and Prat [2006] and Puglisi [2004] incorporate precisely this source of media bias, and show how this can affect public decisions and possibly lead to suboptimal ones.

In this paper we try to gauge the extent of agenda bias on economic issues for a large number of U.S. newspapers over the period 1996-2005. For newspapers belonging to chains or with large circulation we go back to 1988. Exploiting the NewsLibrary electronic archive, we collected monthly and quarterly data on the number of articles that each newspaper reported on some relevant economic issues. ${ }^{1}$ These data can be matched with the actual economic figures to try to assess whether outlets systematically over-report or under-report on given issues as a function of those

\footnotetext{
${ }^{1}$ Making use of the newspapers' own archives and the Factiva electronic archive we integrate this dataset with similar information on the New York Times, the Los Angeles Times and the Chicago Tribune, which are not available on the NewsLibrary archive.
} 
figures and of the party affiliation of the incumbent president. For example, an outlet with a proDemocratic bias might devote more (less) space to news on unemployment when the president is Republican (Democrat) and unemployment is high or rising. We focus on the political affiliation of the incumbent president, because - as consistently shown by a large literature (see e.g. Fair [1978], Tufte [1978], Hibbs [1987], Erikson [1989]) - the performance of the economy under his mandate is a strong determinant of his (or his party's) vote during the next presidential elections. ${ }^{2}$

Differently from other studies on this topic, we do not make any claims about the absolute political bias of U.S. newspapers. Instead, we are interested in the political position of the newspapers relative to each other. In particular, our strategy consists in detecting agenda-setting behavior by exploiting prior knowledge on the political leaning of the newspapers. We investigate whether there is any cross-sectional correlation between the differential coverage of economic issues - as a function of the political affiliation of the incumbent president - and more explicit measures of political orientation, in particular the endorsements of political candidates. In other terms, we want to see if the political orientation of newspapers "spills over" from the editorial page, where endorsements are explictly made, to the news section, where differential coverage of the same economic figures can then be interpreted as agenda setting.

We focus on four key economic variables: the unemployment rate, the inflation rate, the federal deficit, and the trade deficit. These all represent "bads": The incumbent president might be blamed by the public for high values, or rewarded for low values. Hence, we check whether newspapers that have a higher propensity to endorse Democratic candidates give less coverage to a given economic issue when the incumbent president is a Democrat and the corresponding economic indicator is high and/or rising, compared to the coverage of newspapers that have a propensity to endorse Republicans. Formally, this amounts to using a regression specification containing a three-way interaction term. Moreover, since we do not know whether levels or changes in the economic figures are more newsworthy, we consider both specifications that focus on levels and specifications that consider changes.

We find fairly robust evidence of political partisanship in the coverage of the unemployment

\footnotetext{
${ }^{2}$ On this account, MacKuen, Erikson and Stimson [1992] posit an indirect mechanism of influence, whereas the state of the economy (in particular the unemployment rate and GDP growth) affects the perceptions voters have about it, which in turn affects the approval rate of the incumbent president and his vote percentage during the next elections. On the contrary, as discussed by Erikson [1990], there is no robust evidence suggesting that the economy has any significant effects on congressional elections.
} 
rate. We find that newspapers with a pro-Democratic endorsement pattern systematically publish fewer pieces about unemployment when the national unemployment rate is high and the president is Democratic than when the national unemployment is equally high and the president is a Republican. The size of the estimated effects is not negligible. When the unemployment rate was one percentage point above the average, newspapers with a strong propensity to endorse Republican candidates reacted with $15 \%$ per month more articles under Clinton than under Bush. For the same one percent increase, newspapers with a strong pro-Democratic endorsement policy have $9 \%$ less news on unemployment under Clinton than under Bush. We find instead no evidence of partisan bias in the coverage on any of the other economic variables we consider.

Following a recent paper by Gentzkow and Shapiro [2007] on the determinants of the ideological slant of the language used by U.S. newspapers, we also check whether the agenda bias found for unemployment coverage depends on demand, i.e. the partisanship of readers.

While newspapers more heavily sold in Democratic areas indeed tend to give more coverage to high unemployment under Bush than under Clinton as compared to those sold in Republican areas, this correlation is no longer significant when controlling for the ideological leaning of endorsements, properly interacted. On the other hand endorsement partisanship still matters, i.e. Democratic endorsing newspapers ceteris paribus give systematically more coverage to high unemployment under Bush than under Clinton as compared to Republican endorsing ones. On this account, agenda bias in economic news seems more connected with the partisan position of editors, i.e. a supply factor, rather than with the ideological tastes of readers.

A salient feature of our approach is that we code newspaper articles through an automatic keyword search, instead of a human-based content analysis. One advantage of this procedure is that, by definition, it is not intensive in the usage of human capital. Its low cost means that it can be used to gather data on a large number of news outlets for a long time span, restricted only by availabilities in digital archives. More importantly, an automatic search is easily replicated, as it is based on known set of words and/or sentences that are used as classifiers.

In addition, as Antweiler and Frank [2005] argue, using automated text-classification procedures may reduce the risk of certain types of bias. They note that automated searches allow researchers to investigate a comprehensive dataset of news items, possibly the entire population of interest. Because of its cost, studies employing human-based content analysis must instead focus on a small 
subset of the relevant population - in our case, this would likely mean limiting attention to a few media outlets, making it difficult to relate the time variation in the coverage of economic issues to an index of the explicit partisan position of each outlet. This increases the risk of various biases, including publication bias - i.e., the tendency to over-publish and over-cite significant and seemingly interesting results. As Antweiler and Frank point out, researchers and scientific journal editors enjoy considerable freedom to engage in cherry-picking, because the universe of studies employing human-based content analysis is so large. The comprehensive data treatment allowed by automated procedures reduces this type of bias, by sharply restricting the "degrees of freedom" available to the researcher. In our case, for example, we simply choose to focus on the coverage of relevant economic issues by U.S. newspapers during recent times. Once we have made this choice, we measure this coverage on all newspapers that are available in the NewsLibrary archive (plus the New York Times, the Chicago Tribune and Los Angeles Times, which we add because they are the largest newspapers in the U.S. that endorse candidates but are not searchable through NewsLibrary).

One limitation of our approach is that we only classify articles according to the topic covered, without attempting to code whether their tone is positive or negative. Our focus is therefore exclusively on the agenda-setting behavior of newspapers, not on the framing of issues through an intentional or unintentional choice of words. Coding for tone is difficult, especially when dealing with such a nuanced object as a newspaper article, even using human-based content analysis. Unless the analyst provides detailed instructions, inter-coder reliability typically falls far short of acceptable standards. And when the analyst's instructions are very detailed, then results are likely to be driven by these instructions. This suggests that coding for the tone using an automated procedure is also likely to be quite difficult. We view it as an important challenge for future research, however, since the replicability of machine-based content analysis constitutes an extremely valuable feature for the scientific study of mass media. 


\section{Related Literature}

The theory of agenda setting is built around the idea that mass media can influence the importance attached to different issues by readers and viewers. ${ }^{3}$ As Lippmann [1922] notes, news provided by the mass media are a primary source of information about public affairs, and sometimes the only one. Beginning with the seminal contribution by McCombs and Shaw [1972] on Chapel Hill voters, a host of empirical studies have searched for the presence of agenda-setting effects, i.e. of a causal relationship that goes from the coverage of issues on the mass media to the priorities of the public. Experimental evidence, such as that provided by Iyengar, Kinder and Peters [1982], lends the strongest support to this hypothesis. Importantly, the choice of the topics covered by the media need not be politically neutral. There are several ways that media sources can try to use their agenda-setting power to favor one political party or the other.

One way is to exploit the fact that citizens often think that given problems are better handled by one of the parties. This is the notion of "issue ownership", as introduced by Petrocik [1996], who found that on some issues a majority of citizens consistently perceives one party to be more competent than the other. These are the so called "owned issues". For example, U.S. citizens on average believe that the Democratic Party is more competent at managing problems related to welfare and civil rights, while the Republicans are perceived as more competent on defense. ${ }^{4}$

In some cases citizens lack consistent opinions about which party is better at handling a given problem, but they can update their beliefs on the basis of the past and current performance of the incumbent government with respect to that problem. The economy is a primary example of a "performance issue". News about the economy are good news for the incumbent government if the economy is going well, and bad news if the economy is going badly.

If mass media outlets have political preferences and can influence the agenda, then there should be a consistent relationship between the preferences of the outlets and the way economic issues are covered, as a function of the true economic datum and the "match" between these preferences and the political affiliation of the incumbent administration. From this perspective, our empirical exercise provides a test of whether newspapers cover economic news in a manner consistent with

\footnotetext{
${ }^{3}$ For more detailed surveys about the literature on agenda-setting effects, see Erbring, Goldenberg and Miller [1980], Iyengar, Kinder and Peters [1982], Iyengar and Simon [2000] and McCombs [2002].

${ }^{4}$ On the basis of Gallup Polls and NES data, Puglisi [2006] provides some additional evidence on issue ownership perceptions in the U.S. from 1948 to 1996.
} 
the agenda setting hypothesis and with the existence of differences in their political orientation.

Our paper is also related to the growing empirical literature analyzing the political biases of the mass media in the United States.

Ansolabehere, Lessem and Snyder [2006] use panel data to study the political orientation of endorsements of U.S. newspapers. They find that, while in the 40s and in the 50s Republican candidates received more endorsements, this advantage has constantly declined in subsequent decades: in the 90s the authors find a slight Democrats' lead (10\%) in the average endorsement choice. They also find an upward trend in the average propensity to provide endorsement for candidates already in office. In the 1940s incumbent candidates received $60 \%$ of the total endorsements, but this figure has increased to about 90\% today. Fridkin Kahn and Kenney [2002] analyze how large newspapers covered 67 Senatorial campaigns across three election years, as a function of their explicit endorsement choices. Through human-based content analysis they code the tone of the articles and find that newspapers systematically gave a more favorable coverage to endorsed incumbents.

Lott and Hassett [2004] find an overall liberal bias in the U.S. press. They study a panel of 389 U.S. newspapers from 1991 to 2004 (and a sub-sample of them from 1985 to 2004), focusing on economic news, i.e. looking at how newspapers cover the release of official data on a set of economic indicators. Their identification strategy is based on the fact that newspapers can provide a more positive or negative account of the same statistical figure, depending on the party affiliation of the incumbent president. Lott and Hassett find that there are, on average, between 9.6 and 14.7 percent fewer positive stories when the incumbent president is a Republican, controlling for the economic data being released. Differently from our paper, the main focus of Lott and Hassett is on the tone of coverage and the absolute average political position of U.S. newspapers. They do not estimate different positions for different newspapers.

Groseclose and Milyo [2005] also find a liberal bias in the U.S. press. They trace out which think tanks are quoted by each media outlet considered in their sample. The political leaning of each think tank is recovered by looking at the political position (ADA score) of members of the U.S. Congress who quote the same think-tank in a non-negative way. The political leaning of each outlet can then be calculated by looking at the frequency with which the various think thanks are quoted. Groseclose and Milyo find that all the outlets in their sample - except Fox News' Special Report and the Washington Times - are located to the left of the average Congress 
member. At the same time, all outlets but one are located between the average Democrat and the average Republican Congressmen, hence displaying a high degree of centrism. In a similar fashion, Gentzkow and Shapiro [2007] provide another measure of media bias based on similarities between the language used by media outlets and congressmen. Exploiting the Congressional Record, they identify "partisan" words and phrases - i.e., those expressions that show the largest difference in the frequency of use between Democratic and Republican representatives. They then measure how frequently these expressions appear in different newspapers. They conclude that the partisan bias of newspapers depends mainly on consumers' ideological leaning and far less on the identity of owners.

An account of the agenda setting behavior of the New York Times in the period 1946-1997 is provided by Puglisi [2006], who finds that the Times displays Democratic partisanship, with some watchdog aspects. Puglisi finds that, during presidential campaigns, the New York Times systematically gives more coverage to Democratic topics (civil rights, health care, labor and social welfare ) when the incumbent president is a Republican. The New York Times displays a more symmetric type of watchdog behavior after 1960: in the last four decades, during presidential campaigns the Times also gives more coverage to the typically Republican issue of Defense when the incumbent president is a Democrat, and less so when the incumbent is a Republican.

Finally, a different and less studied type of bias consists in the overprovision of news that are of interest to a worthy audience, i.e. an audience which is more valuable to advertisers. A formal model that illustrates this mechanism is provided by Stromberg [2004], while evidence on the UK is given in Larcinese [2007].

Recent advances have also been made regarding the effects of mass media on political decisions and attitudes. Gerber, Karlan and Bergan [2006] conduct a randomized control trial just prior to the November 2005 gubernatorial election in Virginia and randomly assign individuals in Northern Virginia to (a) a treatment group that receives a free subscription to the Washington Post, (b) a treatment group that receives a free subscription to the Washington Times, or (c) a control group. They find that individuals who were assigned to the Washington Post treatment group were eight percentage points more likely to vote for the Democrat in the 2005 election, while those who were assigned the Washington Times were only four percentage points more likely to vote for 
the Democrat. ${ }^{5}$ DellaVigna and Kaplan [2007] use a quasi-experimental approach, and exploit the gradual introduction of Fox News in cable markets in order to estimate its impact on the vote share in presidential elections, between 1996 and 2000. They find that Republicans gained 0.4 to 0.7 percentage points in the towns which started to broadcast Fox News before 2000.

To sum up, our paper shares with Groseclose and Milyo [2005] and Gentzkow and Shapiro [2007] the focus on relative rather than absolute political positions of U.S. media outlets and with Lott and Hassett [2004] the focus on economic news. However, it is the only paper that analyzes the agenda setting behavior of media outlets. ${ }^{6}$ On a methodological ground, ours is the first paper that combines machine-based replicable data on news with information on explicit endorsement patterns.

\section{$3 \quad$ Data and empirical strategy}

We collected data from the NewsLibrary electronic archive, recording the monthly number of hits on unemployment and inflation, and the quarterly number of hits on the federal budget deficit and the trade deficit. ${ }^{7}$ First, through a number of preliminary searches we defined the exact wording of the search strings in order to reduce the number of false positive and false negative hits. Once identified the appropriate keywords (reported in Table 1), we run an automated search, then retrieving the number of hits on each topic by time unit. Overall, we collected data on 140 U.S. newspapers for which electronic archives dating back to 1996 are available to be searched through NewsLibrary. ${ }^{8}$

In this section we will first illustrate the procedure used to recover the endorsement propensity of the various newspapers. We will then present the economic news data and a two-stage preliminary investigation of the data. This illustrates our empirical strategy, although in a less rigorous fashion. We will then be ready to present our panel specification.

\footnotetext{
${ }^{5}$ The latter effect is not statistically significant. However, it is not possible to reject at ordinary confidence levels the null hypothesis that the effects of the two treatment groups on the probability of voting Democrat are equal.

${ }^{6}$ The only exception is Puglisi (2006), who analyses the agenda-setting behavior of the New York Times.

${ }^{7}$ The official macroeconomic figure is made available to the public monthly for the unemployment and the inflation rate, and quarterly for the two deficits.

${ }^{8}$ As mentioned in the introduction, we use the newspapers' own archives to add data on the Los Angeles Times and the Chicago Tribune, and the Factiva archive for the New York Times.
} 


\subsection{The endorsement data}

We were able to gather endorsement data for 102 newspapers. Table A1 lists the newspapers with endorsement data, together with the chain to which they belong, if any.

We obtained the endorsement data for 85 newspapers from Ansolabehere, Lessem and Snyder [2006], and supplemented this with data on 17 additional newspapers searched via the NewsLibrary archive. For the remaining 38 newspapers, in some cases the newspaper has an explicit policy not to endorse candidates for political offices (e.g. the Deseret News in Salt Lake City, the Orange County Register, and the Colorado Springs Gazette). In addition, many smaller ones do not bother to make endorsements, even though they may not take an explicit editorial stance on the subject.

Following Ansolabehere, Lessem and Snyder [2006] we can calculate the propensity of each newspaper to endorse one of the parties during electoral campaigns. We used a linear regression model to estimate the "partisan bias" in endorsement behavior. Let $i$ index offices, let $j$ index newspapers and let $t$ index years. Let

$$
E_{i j t}=\left\{\begin{aligned}
1 & \text { if newspaper } j \text { endorses Democrat for office } i \text { in year } t \\
-1 & \text { if newspaper } j \text { endorses Republican for office } i \text { in year } t \\
0 & \text { if newspaper } j \text { makes no endorsement for office } i \text { in year } t
\end{aligned}\right.
$$

measure the endorsement behavior by each newspaper that makes an endorsement (or an explicit refusal to endorse) in a race. ${ }^{9}$ Also, let

$$
I_{i j t}=\left\{\begin{aligned}
1 & \text { if Democrat for office } i \text { in year } t \text { is only incumbent } \\
-1 & \text { if Republican for office } i \text { in year } t \text { is only incumbent } \\
0 & \text { if otherwise }
\end{aligned}\right.
$$

measure the incumbency status of the candidates in each race. ${ }^{10}$ Finally, we use previous electoral experience to measure non-incumbent quality. Specifically, define a "high-quality" candidate as a candidate who currently holds a U.S. House seat or an elected statewide office other than the office

\footnotetext{
${ }^{9}$ There are a few cases in our sample where a newspaper endorsed both candidates in a race. We drop these from our analysis.

${ }^{10}$ After redistricting there are some U.S. House races with two incumbents running, in which case $I_{i j t}=0$. There are a few such cases in our sample. If we drop them the results are unchanged.
} 
sought. Let

$$
Q_{i j t}=\left\{\begin{aligned}
1 & \text { if Democrat for office } i \text { in year } t \text { is only high quality non-incumbent } \\
-1 & \text { if Republican for office } i \text { in year } t \text { is only high quality non-incumbent } \\
0 & \text { otherwise }
\end{aligned}\right.
$$

We estimated the following linear model for the period 1992-2002, exploiting the panel nature of the data ${ }^{11}$

$$
E_{i j t}=N E_{j}+\theta_{t}+\beta_{1} I_{i j t}+\beta_{2} Q_{i j t}+\epsilon_{i j t}
$$

The newspaper-specific fixed effects, $N E_{j}$, capture newspapers' partisanship. ${ }^{12}$ Figure 1 reports the histogram of the resulting estimated variable. In the graphic, 0 is the neutral point, positive values indicate a propensity to endorse Democratic candidates and negative values a propensity to endorse Republican candidates. The endorsement variable, which is only based on editorials, indicates a slight prevalence, on average, of pro-Democratic endorsements. On the other hand, it also shows a wider dispersion on the Republican side: in other words there is a prevalence of pro-Democratic endorsers but Republican endorsers tend to be more systematic. Overall, however, most newspapers appear to be centrist, in the sense that they are placed in the range $[-0.5,0.5]$ in the endorsement scale (i.e. within the vertical lines). Figure 2 features a scatter plot in which the Democratic endorsement score for each newspaper is represented on the horizontal axis, while the vertical axis displays the average circulation in 1996. Newspapers selling more than 400,000 copies are represented by their name, and smaller papers are represented with dots. Interestingly, the larger newspapers tend to be relatively centrist in their endorsement behavior, as they are typically placed in the range $[-0.5,0.5]$ on the endorsement scale. The more partisan newspapers, outside this range, tend to have more modest circulation.

The question we address is now whether partisanship is only limited to endorsements or rather, in a less transparent way, it is reflected in the coverage of economic news in an agenda-setting fashion. To do this we need to compare newspapers' coverage of given issues with the actual statistical figures on inflation, unemployment, budget deficit and trade deficit.

\footnotetext{
${ }^{11}$ The panel is unbalanced, since we do not have endorsement data on some newspapers in the earlier years.

${ }^{12}$ The model also includes year fixed-effects, $\theta_{t}$, to capture partisan tides.
} 


\subsection{The economic news data: a preliminary investigation}

The key variables in our analysis are the values of the four underlying economic indicators, and the amount of newspaper coverage devoted to the four economic issues. Since newspapers vary greatly in size cross-sectionally (total number of pages, stories, and words), and can also vary in size over time, we focus on the relative frequency of stories in each newspaper. Table 1 reports the keywords that we use ${ }^{13}$.

Let $E V_{t}^{i}$ be the value of the economic figure regarding issue $i$ at time $t$, where $i \in\{U, I, B, T\}$ and $U$ stands for "unemployment", $I$ for "inflation", $B$ for budget deficit, and $T$ for trade deficit. Let $n_{j t}^{i}$ be the relative frequency of pieces published by newspaper $j$ during time $t$ about issue $i .{ }^{14}$

In order to take into account the differences in the average amount of coverage devoted to economic news by the various newspapers, we normalize the relative frequency of stories in newspaper $j$ on issue $i$ at time $t$ by subtracting the average relative frequency of stories in that newspaper, i.e. we consider

$$
y_{j t}^{i}=n_{j t}^{i}-\bar{n}_{j}^{i}
$$

For each newspaper $j$ and each economic issue $i \in\{U, I, B, T\}$, we then run a separate OLS regression:

$$
y_{j t}^{i}=\alpha_{j}^{i}+\beta_{j}^{i} E V_{t}^{i}+\gamma_{j}^{i} D P_{t}+\delta_{j}^{i}\left(E V_{t}^{i} \cdot D P_{t}\right)+\zeta_{j}^{i} t+\lambda_{j}^{i} \ln s_{j t}+\epsilon_{j t}^{i}
$$

where $D P_{t}$ is a dummy variable indicating that the incumbent president is a Democrat. In addition, we control for a linear time trend and for the logarithm of the total number of articles in each newspaper at time $t, s_{j t}$. The coefficient $\delta_{j}^{i}$ represents the difference in how newspaper $j$ reacts to bad economic news when the president is Democratic compared to when the president is a Republican. Positive values indicate that the newspaper is more reactive to bad economic news when the incumbent president is a Democrat ${ }^{15}$

\footnotetext{
${ }^{13} \mathrm{~A}$ potential concern is that all the variation in the coverage of economic news might be driven by editorials themselves. Hence, we have re-run the searches excluding the words "editorial" or "editor". We explore the robustness of our results to this narrower definition of coverage in section ??. We proxy the total number of stories in each newspaper in each period by running a search on the word "and".

${ }^{14}$ Table 2 displays summary statistics of the relative frequency of stories and the economic figures of interest for the 1996-2005 period.

${ }^{15}$ If we had data for a period long enough to cover numerous presidents, it would be possible to treat this interaction term as a measure of the absolute pro-Republican bias of a newspaper. However, given the short time span available, the time series variation by itself could easily be misleading. In particular, other newsworthy events and issues could be crowding out economic news more in some years than others.
} 
Next, we exploit the information we have about the explicit political position of each newspaper, as proxied by its endorsement pattern. In Figures 3-6 we analyze the relationship between the estimated interaction terms from equation (2) and the estimated propensity to endorse Democratic candidates obtained from equation (1). Again, we explicitly report the names of newspapers with circulation above 400,000 copies. The two vertical lines - at $\widehat{N E}_{j}=-0.5$ and $\widehat{N E}_{j}=0.5-$ divide the sample of newspapers, crudely, into those with pro-Republican endorsement pattern, those with a relative neutral patterns, and those with a pro-Democratic pattern. Each graph also displays a bivariate regression line, i.e. the fitted values of a regression of $\widehat{\delta}_{j}^{i}$ over $\widehat{N E}_{j}$ and a constant.

In the case of unemployment news (Figure 3), the relationship between the endorsement variable and the estimated interaction term is negative and statistically significant at the $95 \%$ confidence level, using heteroskedasticity-robust standard errors. This indicates that newspapers with a proDemocratic editorial partisanship tended to give less coverage to unemployment during periods of high unemployment under Clinton than under George W. Bush, as compared to newspapers with a pro-Republican endorsement partisanship. The opposite is true during periods of low unemployment.

Figure 4 displays results regarding the coverage of inflation. The fitted values show a mild and positive relationship between the endorsement variable and the estimated interaction terms. However, this relationship is statistically insignificant $(\mathrm{t}$-value $=0.49)$. Figure 5 represents the same relationship for the coverage of the budget deficit. In this case the estimated slope is negative and statistically insignificant $(\mathrm{t}$-value $=1.24)$. Finally Figure 6 shows the results for the trade deficit, and shows a mildly negative but statistically insignificant relationship $(\mathrm{t}$-value $=0.32)$ between the estimated interaction terms and the endorsement variable.

\subsection{Panel specification}

This simple two-stage graphical analysis gives a mixed picture of the link between endorsement policy and coverage of economic news. On one hand we find some evidence of a partisan bias in the amount of coverage devoted to unemployment. On the other hand, we find small and statistically insignificant relationships for inflation, the budget and the trade deficit.

Here, we perform a more structured test. Rather than analyzing newspapers one at a time, we exploit fully the panel nature of our data. We will therefore estimate three-way specifications 
containing an interaction term between the economic variable $E V^{i}$, an indicator for Democratic president $D P_{t}$ and the newspaper-specific endorsement propensity $\widehat{N E}_{j}{ }^{16}$. A basic three-way specification is the following (we omit the indicator $i$ of the economic issue): ${ }^{17}$

$$
\begin{aligned}
n_{j t}=\quad \alpha_{j}+ & \beta_{1} E V_{t}+\beta_{2} \Delta E V_{t}+\gamma D P_{t}+\delta\left(E V_{t} \cdot D P_{t}\right)+\xi\left(D P_{t} \cdot \widehat{N E}_{j}\right)+ \\
& +\vartheta\left(E V_{t} \cdot \widehat{N E}_{j}\right)+\phi\left(E V_{t} \cdot D P_{t} \cdot \widehat{N E}_{j}\right)+\zeta_{j} t+\lambda \ln s_{j t}+\epsilon_{j t} \quad \text { (Specification A) }
\end{aligned}
$$

where we include newspaper fixed effects $\alpha_{j}$, newspaper-specific trends $\zeta_{j}$ and sensitivity to newspaper size (in logarithm) $\lambda$. We also control for the change $\Delta E V_{t}$ in the economic variable. Our coefficient of interest is $\phi$. A negative value of $\phi$ implies that newspapers which tend to endorse Democratic candidates have a relatively pro-Democratic agenda-setting bias (on economic item $i$ ), compared to newspapers that tend to endorse Republican candidates. In this specification we cannot include time specific dummies since we have other variables that, in each given period, do not vary across newspapers. However, time dummies can be quite important in order to capture the influence that contemporaneous events can have on the space devoted to economic news. Hence, in a second specification we include time-dummies $\tau_{t}$ but exclude other variables that, in each period, do not vary across newspapers:

$$
n_{j t}=\alpha_{j}+\tau_{t}+\xi\left(D P_{t} \cdot \widehat{N E}_{j}\right)+\vartheta\left(E V_{t} \cdot \widehat{N E}_{j}\right)+\phi\left(E V_{t} \cdot D P_{t} \cdot \widehat{N E}_{j}\right)+\zeta_{j} t+\lambda \ln s_{j t}+\epsilon_{j t}
$$

(Specification B)

Finally, in our most demanding specification, we replace $\xi\left(D P_{t} \cdot \widehat{N E}_{j}\right)$ and $\vartheta\left(E V_{t} \cdot \widehat{N E}_{j}\right)$ with, respectively, newspaper-specific Democratic president effects and newspaper-specific issue-variable effects:

$$
n_{j t}=\alpha_{j}+\zeta_{t}+\beta_{j} x_{t}+\gamma_{j} D P_{t}+\phi\left(E V_{t} \cdot D P_{t} \cdot \widehat{N E}_{j}\right)+\zeta_{j} t+\lambda \ln s_{j t}+\epsilon_{j t} \quad \text { (Specification C) }
$$

\footnotetext{
${ }^{16}$ From now on, since all specifications include newspaper-specific fixed effects, the dependent variable is simply $n_{j t}^{i}$. Also, to take into account the fact that the fixed effects may not absorb the entire within-newspaper correlation in the error term, we run all regressions clustering the standard errors by newspaper.

${ }^{17}$ In the baseline specification we control for the contemporaneous value of the relevant economic figure $\left(x_{t}\right)$, by itself and properly interacted. For reasons that will be discussed in Section 5.1, we will also re-run all regressions by using lagged values of the economic variables.
} 
This specification is the most general since we allow newspapers to react differently to changes in the president and in the unemployment rate not just in function of their endorsement partisanship but also of any other unobserved newspaper characteristics.

Since it is a priori unclear which aspect of an economic figure is deemed as more newsworthy by editors and journalists (whether it is the level thereof, or the change, or both), we also re-consider the same three specifications by using the change in the relevant economic figure rather than the levels in the interaction terms. In this case we keep the level of the economic variable as a control. We find, however, no significant results when we focus on changes. The tables are therefore not reported but are available from the authors upon request.

\section{Results}

Table 3 displays the results about unemployment, inflation, budget deficit and trade deficit respectively. We report t-statistics in brackets below each coefficient.

The results in Table 3 confirm that newspapers with a pro-Democratic-endorsement pattern, compared to pro-Republican newspapers, give less coverage to unemployment in times of high unemployment under Clinton than under George W. Bush. The three-way interaction between the level of the unemployment rate, the Democratic President dummy and the Democratic endorsement variable always comes with the expected negative sign and is significant at the $5 \%$ level in all three specifications. The magnitude of the coefficient is also very stable across specifications. We find, however, no comparable effect for any of the other economic variables we consider. For inflation, budget deficit and trade deficit the three-way interaction is always very far from any acceptable significance level and therefore statistically indistinguishable from zero.

To calculate the magnitude of the effect for unemployment news we group the newspapers into quantiles on the basis of their endorsement patterns. Then, for each group, we compute the difference between the average predicted change in the number of unemployment stories under

Clinton and under George W. Bush, if the unemployment rate is one percentage point higher than the average. The magnitudes refer to newspapers belonging to the first, third and fifth quintile in the endorsement distribution, i.e. newspapers that we define as, respectively, strongly Republican, "neutral," and strongly Democratic. The estimated effects are not trivial. Newspapers will react 
to a $1 \%$ increase in the unemployment rate differently depending on whether the president is Democratric or Republican: under a Democratic president a strongly Republican newspaper will provide $15 \%$ more news on unemployment than if the same $1 \%$ increase in the unemployment rate happens under a Republican president. On the other side, considering again a $1 \%$ increase in the unemployment rate, a strongly Democratic newspaper will provide $9 \%$ less news on unemployment under a Democratic president than under a Republican president. The differential treatment of the same change under the two presidents is instead limited to $1 \%$ for a "neutral" newspaper.

Some data analysts might be tempted to treat the average difference in slopes across Democratic and Republican presidents (the $\delta \mathrm{s}$ ) as a measure of the average absolute level of bias across the newspapers in our sample. We are not. The reason is that the time sample is too short, so we are only comparing two presidents; the underlying economic conditions were different under the two presidents, so functional form is a major concern; and many other newsworthy events (terrorist attacks, war in Iraq, Monica Lewinsky scandal, O.J. Simpson trial) might have crowded out economic news differentially under the two presidents. Compared to recent literature on media bias (see Lott and Hassett, 2004), we would place little emphasis on such coefficients. ${ }^{18}$ Finally, it is interesting to note that the coefficients on the interaction between the unemployment rate and the endorsement variable (the $\vartheta_{\mathrm{s}}$ ) are positive and statistically significant. In other terms, coverage by Democratic-endorsing newspapers is more reactive to high unemployment than by Republican-leaning ones, even when controlling with the triple interaction for the partisan effect.

\section{Robustness checks}

In this section we check the robustness of our results. We implemented a number of checks for all the economic variables considered and we noticed no change in our conclusion regarding inflation, budget deficit and trade deficit: there is no noticeable statistically significant bias in the covering

\footnotetext{
${ }^{18}$ If one did use the coefficients in this way, the picture would be mixed. The estimated difference in slopes is negative and significantly different from zero in the case of unemployment, inflation and trade deficit, suggesting a pro-Democratic bias. That is, newspapers on average devoted more attention to unemployment (inflation, trade deficit) during periods of high unemployment under George W. Bush than under Clinton, and vice versa for periods of low unemployment. On the other hand, for the budget deficit the estimate suggests a Pro-Republican bias. At the same time, budget deficit and unemployment were generally decreasing under Clinton and were increasing during the George W. Bush years. Hence, it is hard to determine whether the coefficients reflect a partisan bias in coverage or simply a judgement about the importance of the direction of a change (i.e. increases vs. decreases) for a particular economic variable.
} 
of these issues. In this section, therefore, we only report results that concern unemployment, the only economic variable on which we found agenda setting behavior by part of the newspapers.

\subsection{Lagged values of the economic figures}

It is a priori unclear whether newsworthy economic events are more correlated with contemporaneous values of the relevant economic figures, or lagged values. The Bureau of Economic Analysis and the Bureau of Labor Statistics (or any statistical agency assigned to similar tasks) can only publish lagged values of macroeconomic variables. However, newspapers do not only report on the release of official data (which are related to what happened in the past) but also on contemporaneous events which may be correlated with the current value of the relevant macroeconomic figure. For example, with respect to unemployment, there might be news stories on large layoffs in a given sector or by a particular large firm, or reports of large current spikes in applications at local unemployment agencies. It might be useful, therefore, to check if our results are sensitive or not to the presence of lags in the economic variables.

The first three columns of Tab. 4 parallel the first three columns of Table 3 but use lagged instead of contemporary unemployment. The results previously obtained are all confirmed and the magnitudes are also very similar (slightly larger under specifications A and B, slightly smaller using specification $\mathrm{C}$ ). The R-squared also show that the overall fit is comparable in the two cases.

\subsection{Controlling for state-level unemployment}

Newspapers typically have a locally concentrated readership that cares about local events, and local aspects of common phenomena. Since there is noticeable variation in unemployment across regions and states, the local unemployment rate in an area or state may represent a newsworthy issue. This can potentially introduce an omitted variables bias. The concern is that, in Democraticvoting areas, the local unemployment rate could be systematically lower than its average when the incumbent president is a Democrat, because of public job-creating projects being targeted to the area. If the political partisanship of potential readers in the area where a newspaper sells is positively correlated with its endorsement policy, then the less intense coverage of high unemployment by Democratic-leaning newspapers under a Democratic president could be driven by the fact that the local unemployment rate is lower in those areas where the newspapers are sold. This would not 
indicate a partisan bias trickling down from the editorial page to the economic news section, but simple reporting on local economic conditions.

To address this issue, we re-ran our regressions controlling for both the level and change of the unemployment rate in the state where each newspaper is based ${ }^{19}$. The results are reported in columns 4-6 of Table 4. Again we find a systematic correlation between the endorsement policy and the differential coverage of unemployment. The size and significance of the coefficients of the three-way interaction terms are very similar to those reported in Table 3 . The coefficients of the level of the unemployment rate in the state is positive and significant at standard confidence levels. Similarly, the coverage of unemployment is positively and significantly correlated with the change in the state unemployment rate. Consequently, we will keep state unemployment levels and variations as control variables in the next checks.

\subsection{Excluding editorials}

The results found so far could be driven by what is featured on editorial pages themselves. Therefore we repeat our regressions by excluding editorials from our dependent variable. ${ }^{20}$ The results are presented in columns 7-9 of Table 4, again using the same A-B-C specifications and including levels and changes in state unemployment rates. The results are very reassuring: the coefficient of the three-way interaction is again negative and significant, the magnitude is only slightly inferior to what we found in the previous cases. To sum up, a large part of the differential coverage of unemployment takes place on the news pages, not merely on the editorial ones, suggesting that agenda-setting indeed spills over into the economic news section.

\subsection{Chain-based and large newspapers}

Given that we rely on electronic archives, there is a trade off between the length of the time span we can study and the number of newspapers for which data are available. For the period 1996-2005 we can rely on 102 newspapers but this number shrinks rapidly as we extend backward the period

\footnotetext{
${ }^{19}$ Because of multicollinearity problems, while the slope of unemployment news with respect to the national unemployment rate is allowed to be newspaper-specific, the slopes with respect to state level unemployment rate and its change are common across newspapers.

${ }^{20}$ We consider news on unemployment excluding the words "editorial" or "editor". To pin down the size of the news section of each newspaper during each month, we have run a search on the word "and", excluding again the words "editorial" or "editor".
} 
we consider. Using different time windows, our results turn out not to be always robust: ${ }^{21}$ however, we cannot say whether this is due to the usage of a different sample of newspapers or rather to features specific to the period considered. Hence, to mantain some consistency across periods, we explore the robustness of our results for the subsample of large-scale newspapers, i.e. those that sell a large number of copies (above 200,000 copies per day on average in 1996) and/or belong to large chains. ${ }^{22}$ It could be the case that managing editors and journalists of large-scale newspapers are more conscious of the political facets of their agenda setting behavior, and act accordingly. In other terms, the relationship between the endorsement policy and the coverage of economic news might be less noisy (and hence less susceptible to sample size) when restricting our attention to this subset of newspapers.

There are 72 large-scale newspapers if one considers the 1996-2005 time-window. The amount shrinks to 59 in the period 1992-2005 and to 32 for 1988-2005. Table 5 reports our results for the three periods respectively. Once again, the three-way interaction comes with the expected negative sign and acceptable significance levels. For the period 1988-2005 we notice a reduction of about $1 / 3$ in the size of the coefficient compared with the results of Table 3. This reduction is even stronger for the period 1992-2005. On the contrary, when we consider the 1996-2005 period, the coefficient turns out to be substantially larger for chain-based and large newspapers (columns 7-9 in Table 5) than for the whole sample (columns 1-3 in Table 3). In brief, although the magnitudes of the relevant coefficient may vary by a relevant amount, Table 5 substantially confirms all the results we found in the previous regressions.

\subsection{Demand-driven coverage?}

Gentzkow and Shapiro's [2007] thorough analysis of language similarity between congressmen and U.S. newspapers suggests that the ideological position of the latter is strongly correlated with the political leaning of their readers. On the other hand, once geographical factors are taken into account, the owner's identity has very little or no explanatory power on the political leaning of a

\footnotetext{
${ }^{21}$ The statistical significance of the three-way interaction coefficient disappears if we consider the period $1992-$ 2005 but reappears at the 5\% level for the period 1988-2005. Moreover, regarding the 1992-2005 period, if one excludes the Washington Times and/or the Manchester Union-Leader from the sample, the triple interaction comes out strongly significant again. One should notice here that in our sample the Washington Times is the most extreme newspaper endorsement-wise. Moreover, the Union-Leader, a decidedly Republican paper, is the only one based in New Hampshire, which in 1992 was hit by the worst depression of the last forty years.

${ }^{22}$ Details are provided in Table A1.
} 
given newspaper.

In the previous sections we have investigated whether the explicit political position of a newspaper, as proxied by its endorsement choices, trickles down from the editorial to the news section, influencing the coverage of economic news. One might be concerned that editors tune their endorsement choices to the ideological leaning of readers, so that our endorsement variable is merely proxying for a demand factor which also determines economic coverage. According to this view, both endorsement choices and the partisan coverage of economic news are determined by what customers would like to read, with no independent role for the newspaper's editorial position, i.e. a supply factor.

In order to address this concern we proceed as follows. First, as a proxy for the average political position of readers of a given newspaper $j$, we weight the average Democratic vote in presidential, senatorial and gubernatorial elections in each county during the time period by the relative sales of that newspaper in that county. Let this variable be $N R_{j}$. We then replicate our three baseline specifications by replacing the endorsement variable $\widehat{N E}_{j}$ with the readership variable $N R_{j}$. For all three specifications, we also consider an extended model where we include both $\widehat{N E}_{j}$ and $N R_{j}$, properly interacted with the Democratic President dummy $D P_{t}$ and the level $E V_{t}$ of the economic variable.

Table displays results for the contemporaneous unemployment rate. ${ }^{23}$ When not controlling for the endorsement behaviour, the coefficient on the triple interaction between the unemployment rate, the Democratic President dummy and the voter partisanship variable is negative and statistically significant. However, this triple interaction is no longer significant when introducing back the endorsement controls. On the other hand, the coefficient on the triple interaction with the endorsement score is negative and mildly statistically significant even after controlling for readers' partisanship. A relevant concern here is the correlation between reader and endorsement partisanship, which might create problems of approximate multicollinearity when these variables are twice interacted with the same controls (the Democratic president dummy and the level of the unemployment rate). ${ }^{24}$

\footnotetext{
${ }^{23}$ We obtain very similar results (available upon request) when controlling for the lagged level of the unemployment rate.

${ }^{24}$ Indeed, if we introduce newspaper-specific controls for newspaper size instead of a common one, under specification A and B the three way effect with voter partisanship is mildly significant even when controlling for endorsement partisanship. The triple interaction with the endorsement score stays significant under all three specifications. These
} 
However, the raw correlation between the partisanship of endorsements and that of voters is just 0.21 , i.e. quite low. While positive, and statistically significant ( $\mathrm{p}$-value $=.031$ ), it is hardly overwhelming. ${ }^{25}$ Evidently there is a lot of "slack" between voters and editors.

Since it remains difficult to disentangle the direction of causality with data whose relevant variation is ultimately cross-sectional, a possible empirical strategy consists in using time series data and exploit some (possibly) exogenous shock in the partisanship of readers across regions, or in the editorial position of newspapers, as triggered by a change in ownership or management. An interesting case in hand is represented by the succession of Otis Chandler in 1960 as publisher of the Los Angeles Times, the newspaper his family owned since 1884. The LA Times used to have a clear conservative slant, which was overturned by Chandler, who aimed at making it a credible rival of the New York Times. Figure 7 shows the time series variation in the propensity of the LA Times to endorse Democratic candidates, together with the average yearly share of the Democratic vote in presidential, senatorial and gubernatorial elections in California. In the 60s, after Otis Chandler took office, there was a steep increase in the propensity to endorse Democratic candidates, which was not matched at all by a comparatively rapid surge in the Democratic vote.

The top two scatter plots in Figure 8 show the relationship between the actual unemployment rate and the relative frequency of unemployment stories on the LA Times, before and after 1965. In each graph, coverage-unemployment combinations under a Democratic (Republican) President are indexed by a one (zero). The bottom two graphs parallel the top ones, showing the same relationship for the inflation rate. Regression lines between the economic variable and its coverage, as a function of the political affiliation of the incumbent President, are reported. The two scatter plots on the left show that before 1965 the LA Times systematically gave more coverage to high unemployment and inflation under a Democratic President than a Republican one ${ }^{26}$. On the other hand, according to the two graphs on the right, in the post-1965 period there is no systematic difference in the slopes under presidents of different political affiliation.

Ideally, this anedoctal evidence should be backed up by the analysis of a large sample of news-

results are available upon request.

${ }^{25}$ One relevant concern here is that this low correlation might be driven by the presence in the sample of newspapers that are based in large cities with a politically segmented media market, like Chicago, New York and Los Angeles. However, if we exclude those newspapers (in our case the Chicago Sun-Times, the Chicago Tribune, the Los Angeles Times and the New York Times), the resulting correlation slightly drops to 0.2 (p-value $=.045$ ).

${ }^{26}$ This is formally confirmed by proper difference-in-differences regressions, available upon request from the authors. 
papers, with enough time series variation in their ownership and management. However, coupled with our previous analysis of endorsement patterns, it is indicative of the fact that supply side factors might play a non-negligible role in determining the political position of mass media outlets, in this case affecting the partisan coverage of economic news.

\section{Discussion and conclusions}

In this paper we have analyzed the relationship between the endorsement policy of U.S. newspapers and the coverage of economic issues, as a function of the true economic datum and the political affiliation of the incumbent president. Considering the last decade, there is strong evidence that newspapers endorsing Democratic candidates give less coverage to high unemployment (and more coverage to low unemployment) under Clinton than under George W. Bush, as compared to Republican-leaning newspapers. This relationship is very robust to a number of alternative specifications and robustness checks. On the other hand, there is no evidence of a systematic correlation between the endorsement policy and the coverage of inflation, the budget deficit and the trade deficit.

These findings deserve further explorations. On one side, finding evidence of agenda setting behavior only on one economic issue out of four could induce us to reject the idea that there is any relevant ideologically slanted agenda setting in economic news on the U.S. press. On the other side, unemployment is, of the four considered, the most salient issue. Moreover, as discussed in the introduction, there is a large body of evidence according to which citizens assess the incumbent president's performance on the basis of how strong the economy is, and vote accordingly in the next presidential elections. Citizens are also better able to grasp the significance of a high unemployment rate, because of the dire consequences this might have on their personal lives.

This latter statement likely applies to the inflation rate as well, but the independence of the Federal Reserve makes harder for the public to establish links between presidential policies and its variation. Also, even if citizens are largely unaware of the institutional independence of the FED, in the time period under consideration inflation was very low ${ }^{27}$, so that it was not perceived as a serious problem policy makers had to tackle. It is also interesting to note that - in the long run

\footnotetext{
${ }^{27}$ During the 1996-2005 period, the highest inflation rate was about 4.7\% (September 2005). In the 1988-2005 period, the peak of around $6.3 \%$ was reached in October 1990.
} 
analysis of the LA Times presented in section ?? - the succession of Otis Chandler as publisher seemed to matter not only with regards to the partisan coverage of unemployment, but for inflation as well. It is indeed the case that, during the longer time period we considered there, the inflation rate was often higher than in the more recent period, sometimes much higher, like in the late 40s, the $70 \mathrm{~s}$ and the early $80 \mathrm{~s}$. At those times the rise in the cost of living was widely perceived as a very serious issue.

Finally, the budget deficit and the trade deficit are more arcane variables, whose influence on presidential approval is far from clear and whose significance citizens understand much less, perhaps because of the lack of direct effects on their personal lives, perhaps because the effects are not immediate and can therefore be heavily discounted. In the American National Election Studies 1992-2004, unemployment came in second as the "most important problem facing the nation" (crime being first). Nearly 10\% of respondents mentioned it. By comparison, less than 0.5\% of respondents mentioned inflation, and even counting generously, only about $1.5 \%$ of respondents mentioned trade issues (only $0.33 \%$ of respondents mentioned the trade deficit specifically, and more respondents mentioned "international competitiveness" or "outsourcing", which might be treated more appropriately as employment issues). ${ }^{28}$

As mentioned in the introduction, we only study agenda-setting and do not attempt to estimate any framing of economic events done through tone. Another limitation of our approach is that we simply count the number of articles featuring the chosen keywords. ${ }^{29}$

Still, our approach to the study of mass media is very flexible and easily replicable. This allows to readily extend the dataset and type of analysis in several directions. First, it would be worthwhile to try and gather data on additional newspapers for the early 90 s and late 80s, in order to shed some further light on the robustness of our results with respect to the time-window being considered. Moreover, historical electronic archives like ProQuest can be used to construct long time series on the coverage of economic issues by a handful of newspapers. Secondly, any debate on the extent of "mass media bias" in the U.S. should be put into a comparative perspective. ${ }^{30}$

\footnotetext{
${ }^{28}$ Unfortunately, we cannot separate the government deficit from other mentions about government spending being too high.

${ }^{29}$ One could for example refine the search algorithm to code the page number and newspaper section on which each piece appears. In particular, one could give a higher weight to front page stories, or separately consider them in the analysis. A further improvement (which is more difficult to implement within an automated search) would be to weight articles by their length.

${ }^{30}$ See Gentzkow, Glaeser and Goldin [2006] for a time-series comparison of the extent of bias on the U.S. press in
} 
Given that the economy represents a salient issue in almost all countries, one could use the same keywords-based search procedure on the electronic archives of newspapers and media outlets in other countries, and construct similar datasets to the one analyzed here. The purpose of such an exercise would be to compare - on a cross-country basis - the amount of within-country variation in the differential coverage of relevant economic figures, as a function of the political affiliation of the incumbent government and the level itself of the economic figure.

the coverage of two political scandals, the Crédit Mobilier in the 1870s and the Teapot Dome in the 1920s. 


\section{References}

[1] Anderson, S. P. and McLaren, J. [2005]. "Media Mergers and Media Bias with Rational Consumers". Mimeo, University of Virginia.

[2] Ansolabehere, S., Lessem, R. and Snyder, J. M. Jr. [2006]. "The Orientation of Newspaper Endorsements in U.S. Elections, 1940-2002" . Quarterly Journal of Political Science, forthcoming.

[3] Antweiler, W. and Frank, M. Z. [2005]. "Do US Stock Markets Typically Overreact to Corporate News Stories?" Mimeo, Sauder School of Business, University of British Columbia.

[4] Bernhardt, D., Krasa, S. and Polborn, M. K. [2006], "Political Polarization and the Electoral Effects of Media Bias". CESifo Working Paper Series No. 1798, available at SSRN: http://ssrn. com/abstract=892475.

[5] Besley, T. and Prat, A. [2006]. "Handcuffs for the Grabbing Hand? Media Capture and Government Accountability". American Economic Review, 96(3): 720-736.

[6] Cohen, B. [1963]. The Press and Foreign Policy. Princeton, Princeton University Press.

[7] DellaVigna, S. and Kaplan, E. [2007]. "The Fox News Effect: Media Bias and Voting". Quarterly Journal of Economics, forthcoming.

[8] Erikson, R. S. [1989]. "Economic Conditions and The Presidential Vote". American Political Science Review, 83(2): 567-573.

[9] Erikson, R. S. [1990]. "Economic Conditions and the Congressional Vote: A Review of the Macrolevel Evidence". American Journal of Political Science, 34(2): 373-399.

[10] Erbring, L., Goldenberg, E. N. and Miller, A. H. [1980]. "Front-Page News and Real-World Cues: A New Look at Agenda-Setting by the Media". American Journal of Political Science, 24(1): 16-49.

[11] Fair, R. C. [1978]. "The Effect of Economic Events on Votes for President". Review of Economics and Statistics, 60(2): 159-173. 
[12] Fridkin Kahn, K. and Kenney, P. J. [2002]. "The Slant of the News: How Editorial Endorsements Influence Campaign Coverage and Citizens' Views of Candidates". American Political Science Review, 96(2): 381-394.

[13] Gentzkow, M. A., Glaeser, E. L. and Goldin, C. [2006]. "The Rise of the Fourth Estate: How Newspapers Became Informative and Why it Mattered". In Edward L. Glaeser and Claudia Goldin (Eds.), Corruption and Reform: Lessons from America's History. National Bureau of Economic Research.

[14] Gentzkow, M. A. and Shapiro, J. M. [2007]. "What Drives News Media Slant? Evidence from U.S. Daily Newspapers". Mimeo, University of Chicago.

[15] Gerber, A., Karlan, D. and Bergan, D. [2006]. "Does The Media Matter? A Field Experiment Measuring the Effect of Newspapers on Voting Behavior and Political Opinions". Mimeo, Yale University.

[16] Groseclose, T. and Milyo, J. [2005]. "A Measure of Media Bias". Quarterly Journal of Economics, 120(4): 1191-1237.

[17] Hibbs, D. A, Jr. [1987]. The American Political Economy: Macroeconomic and Electoral Politics in the United States. Cambridge, Harvard University Press.

[18] Iyengar, S., Kinder, D. R., and Peters, M. D. [1982]. "Experimental Demonstrations of the "Not-So-Minimal" Consequences of Television News Programs". The American Political Science Review, 76(4): 848-858.

[19] Iyengar, S. and Simon, A. F. [2000]. "New Perspectives and Evidence on Political Communication and Campaign Effects". Annual Review of Psychology 51: 149-169.

[20] Larcinese, V. [2007]: The Instrumental Voter Goes to the News-Agent: Information Acquisition, Marginality, and the Media, Journal of Theoretical Politics, 19(3): 249-276.

[21] Lippmann, W. [1922]. Public Opinion. New York, Harcourt, Brace.

[22] Lott, J. R., Jr. and Hassett, K. A. [2004]. "Is Newspaper Coverage of Economic Events Politically Biased?" Working Paper, American Enterprise Institute, Washington, DC. 
[23] MacKuen, M. B., Erikson, R. S. and Stimson, J. A. [1992]. "Peasants or Bankers? The American Electorate and the U.S. Economy". American Political Science Review, 86(3): 597611.

[24] McCombs, M. E. [2002]. "The Agenda-Setting Role of the Mass Media in the Shaping of Public Opinion". Paper presented at Mass Media Economics 2002 conference, London School of Economics: http://sticerd.lse.ac.uk/dps/extra/McCombs.pdf

[25] McCombs, M. E. and Shaw, D. L. [1972]. "The Agenda-Setting Function of Mass Media". Public Opinion Quarterly, 36(2): 176-187.

[26] Petrocik, J. R. [1996]. "Issue Ownership in Presidential Elections, with a 1980 Case Study". American Journal of Political Science, 40(3): 825-850.

[27] Puglisi, R. [2004]. "The Spin Doctor Meets the Rational Voter: Electoral Competition with Agenda-Setting Effects". Available at SSRN: http://ssrn.com/abstract=581881.

[28] Puglisi, R. [2006]. "Being the New York Times: the Political Behaviour of a Newspaper". Political Economy and Public Policy (PEPP) Working Paper n. 20, STICERD, London School of Economics.

[29] Strömberg, D. [2004]. "Mass Media Competition, Political Competition, and Public Policy". Review of Economic Studies, 71(1): 265-284.

[30] Tufte, E. R. [1978]. Political Control of the Economy. Princeton, Princeton University Press. 
Fig. 1: Histogram of the endorsement propensity: 1992-2005

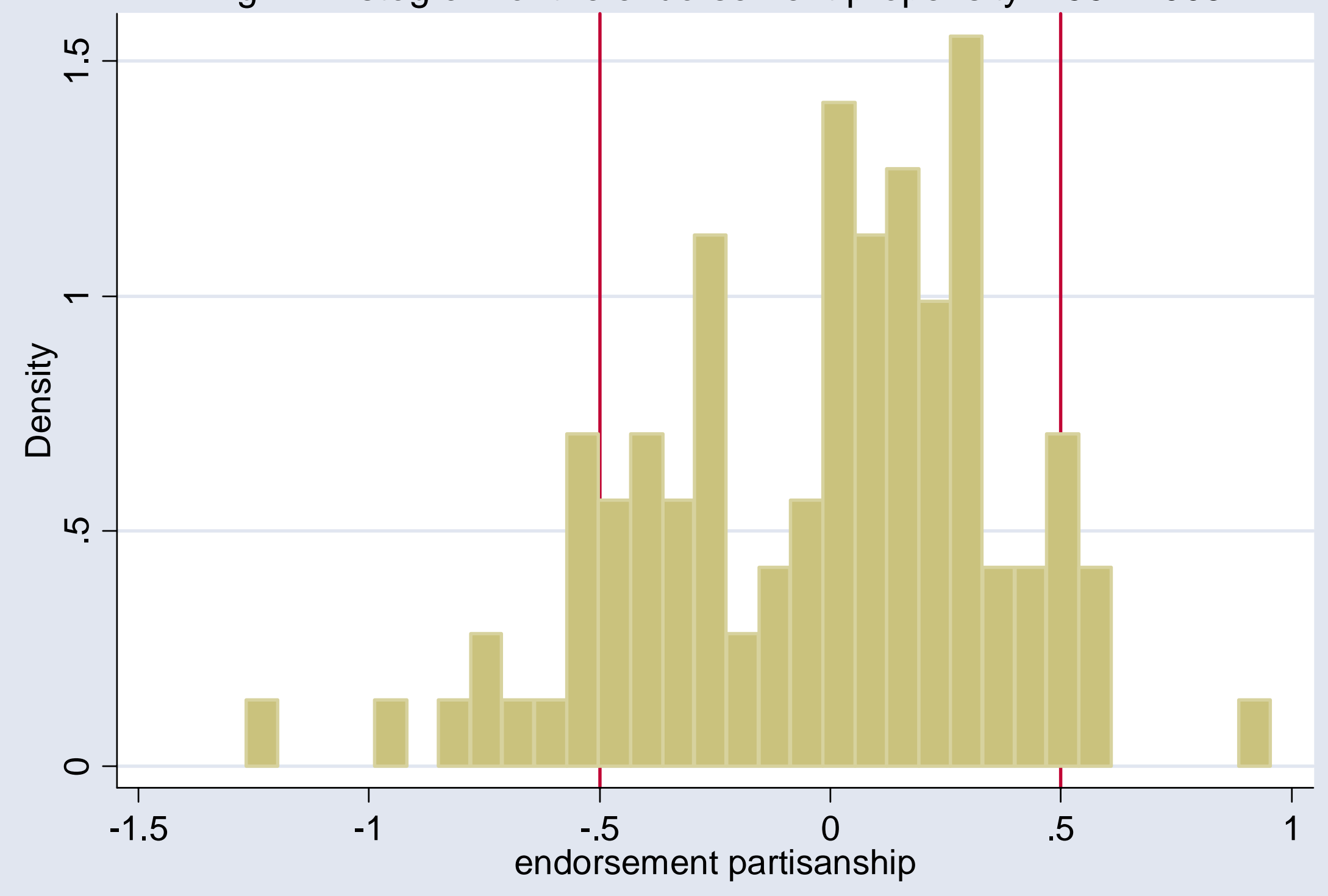




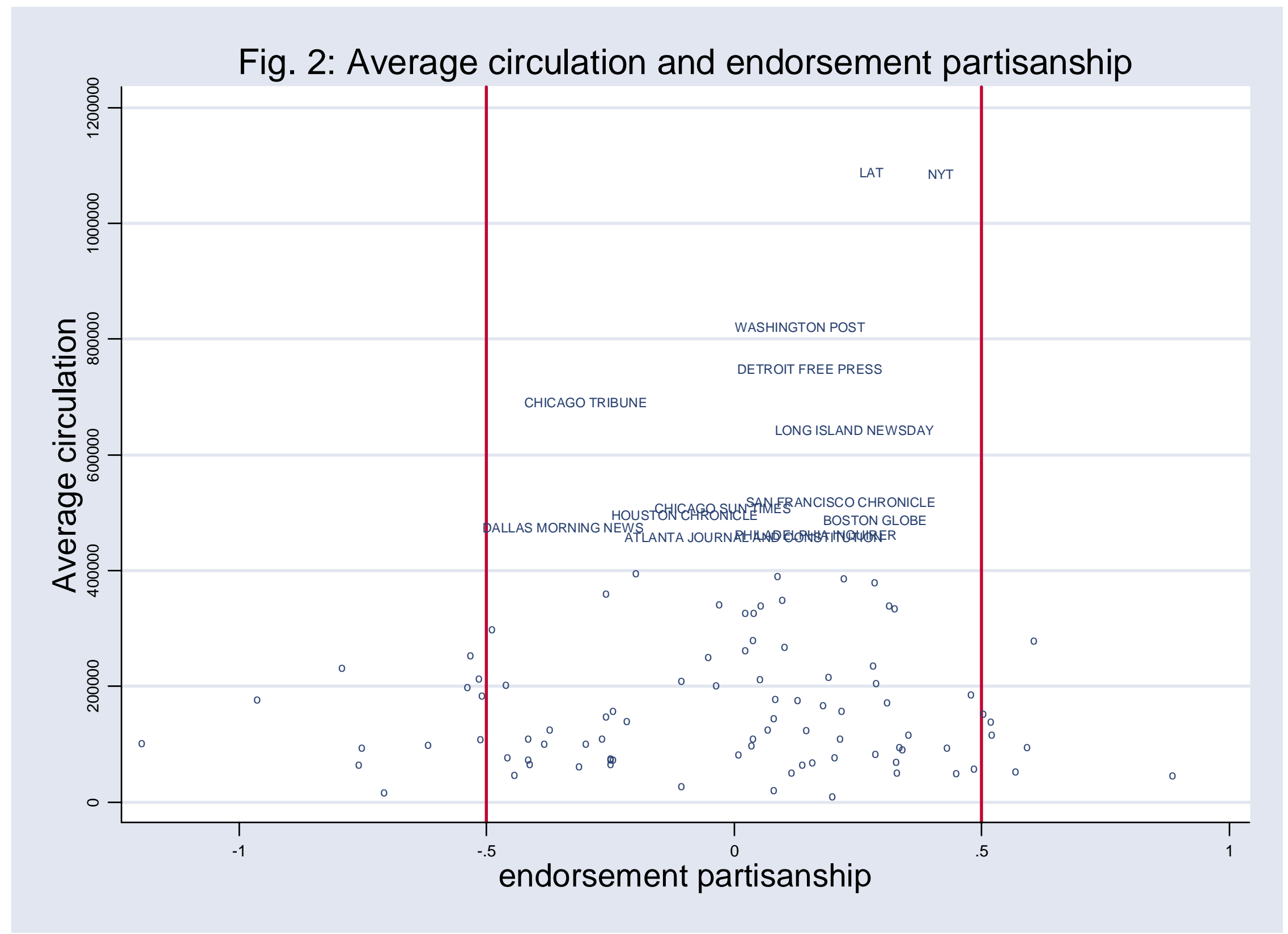


Fig. 3: Endorsement policy and partisan coverage of unemployment

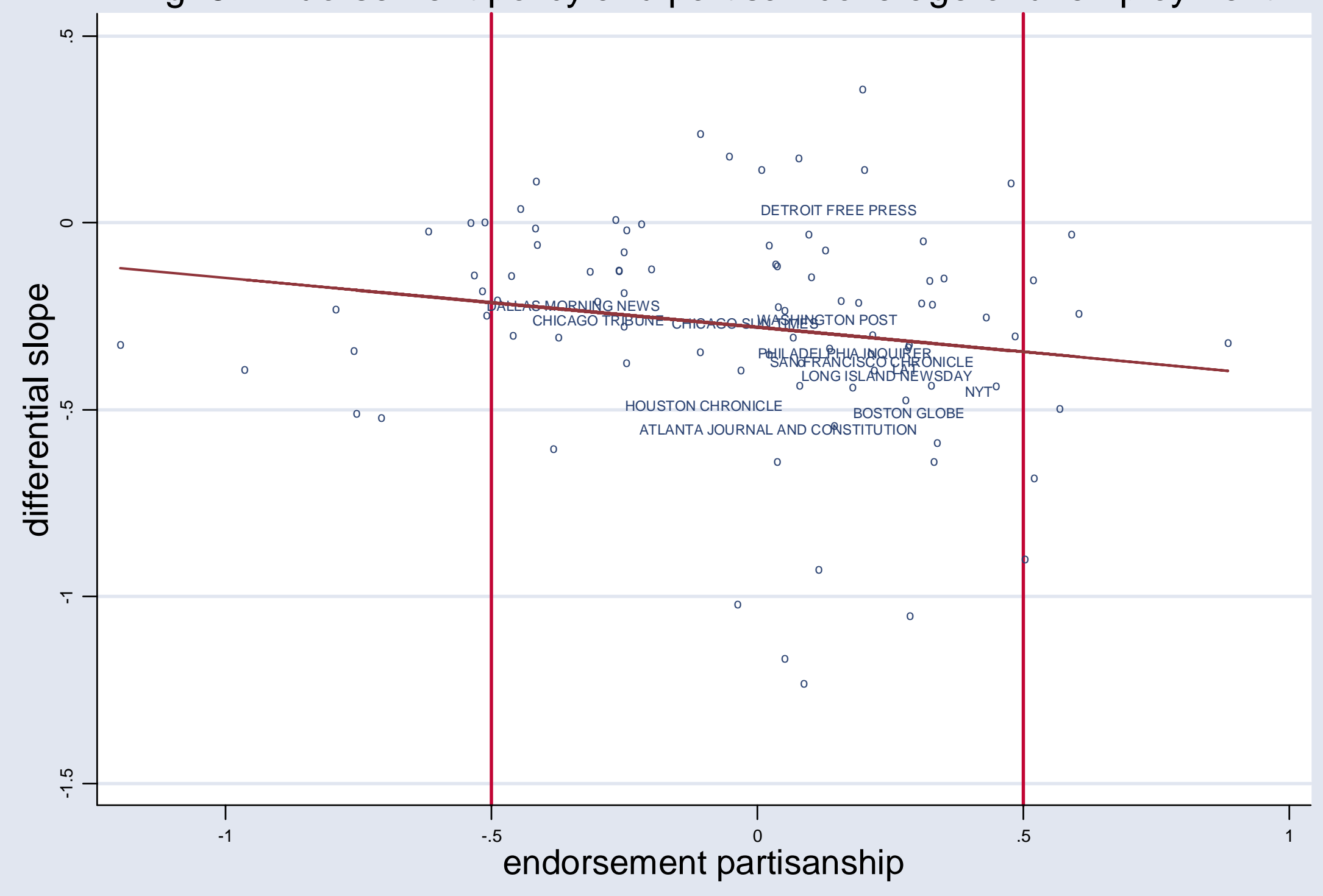


Fig. 4: Endorsement policy and partisan coverage of inflation

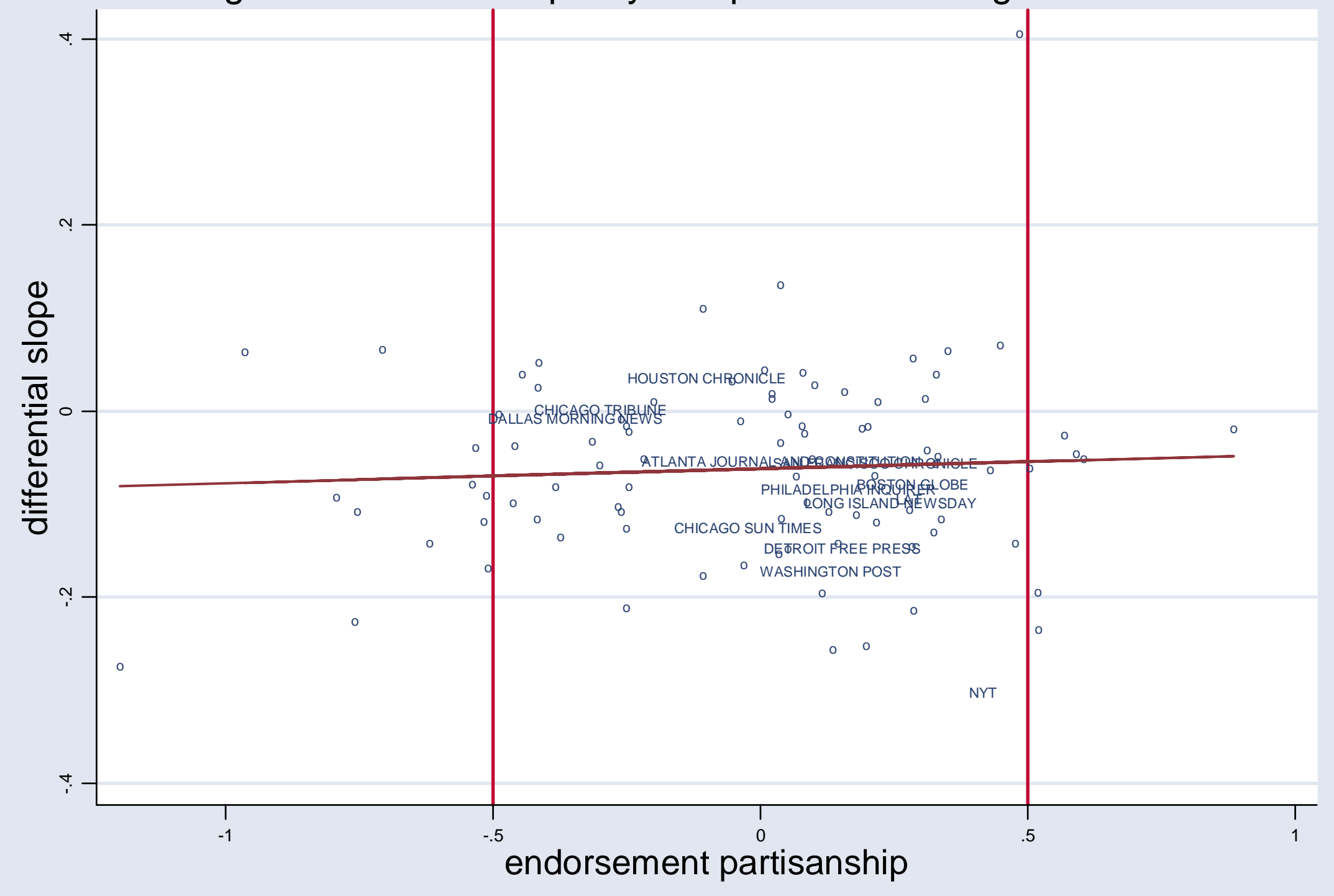




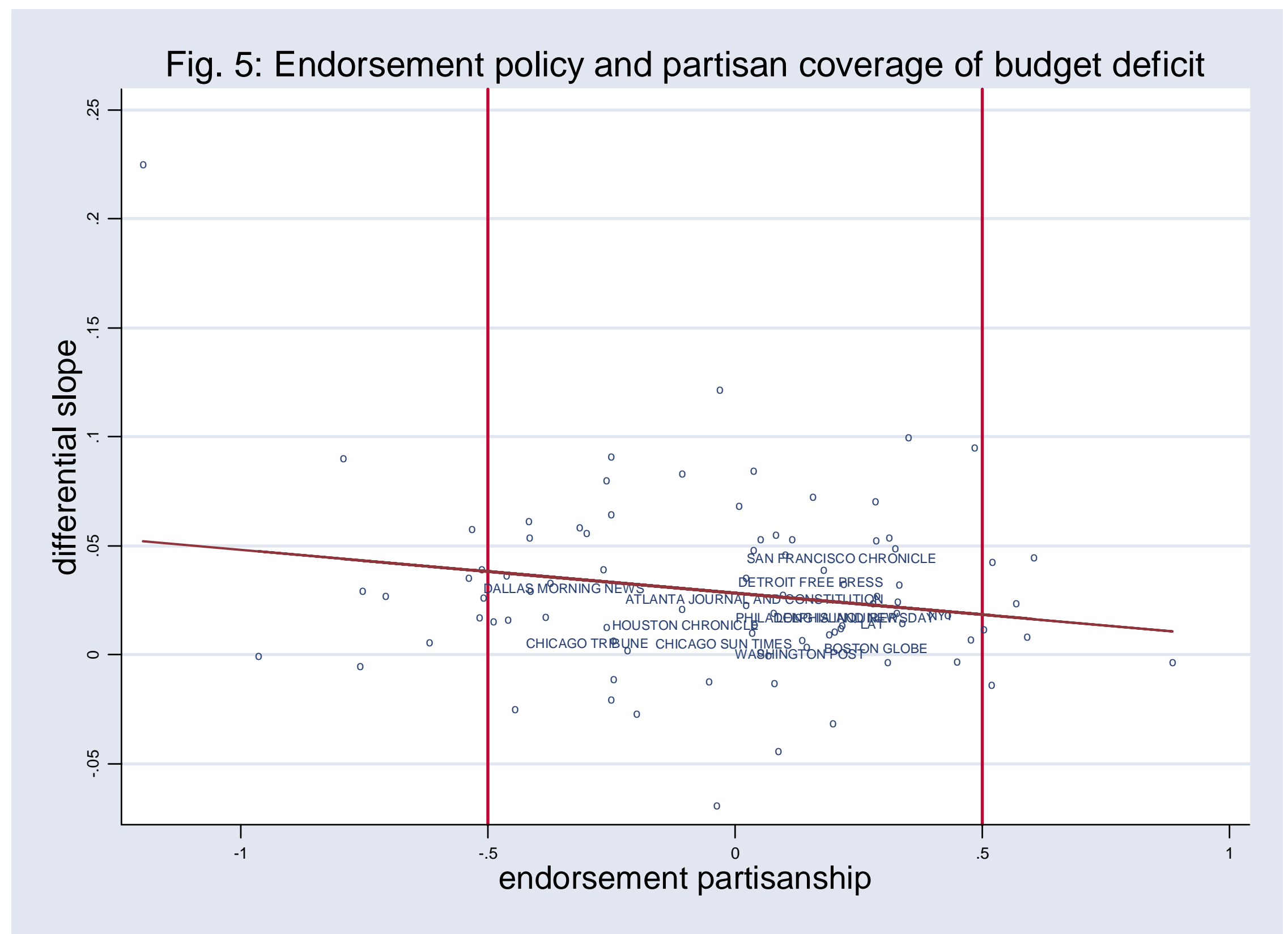


Fig. 6: Endorsement policy and partisan coverage of trade deficit

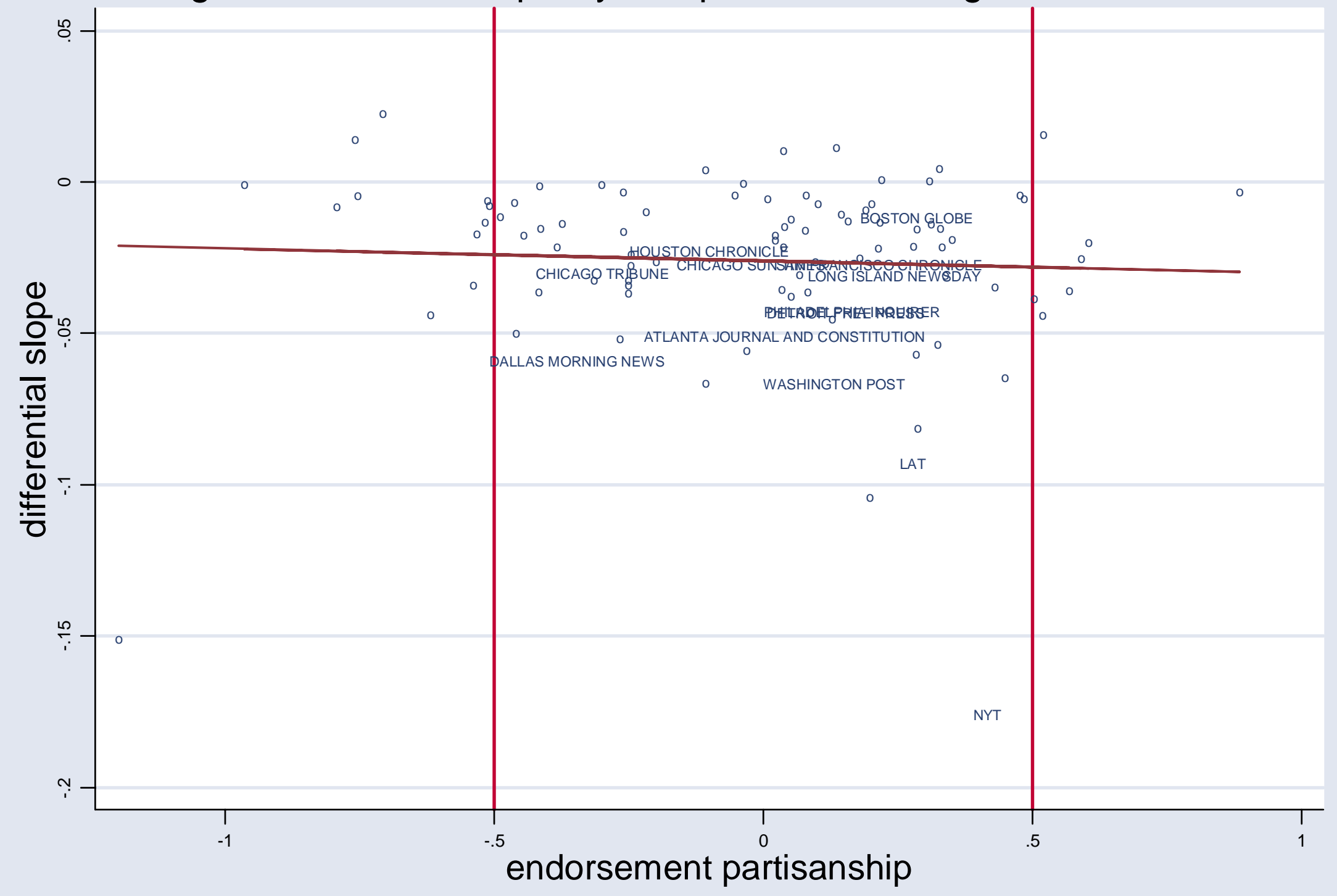


Figure 7: Dynamics of Democratic vote in California and LA Times endorsements

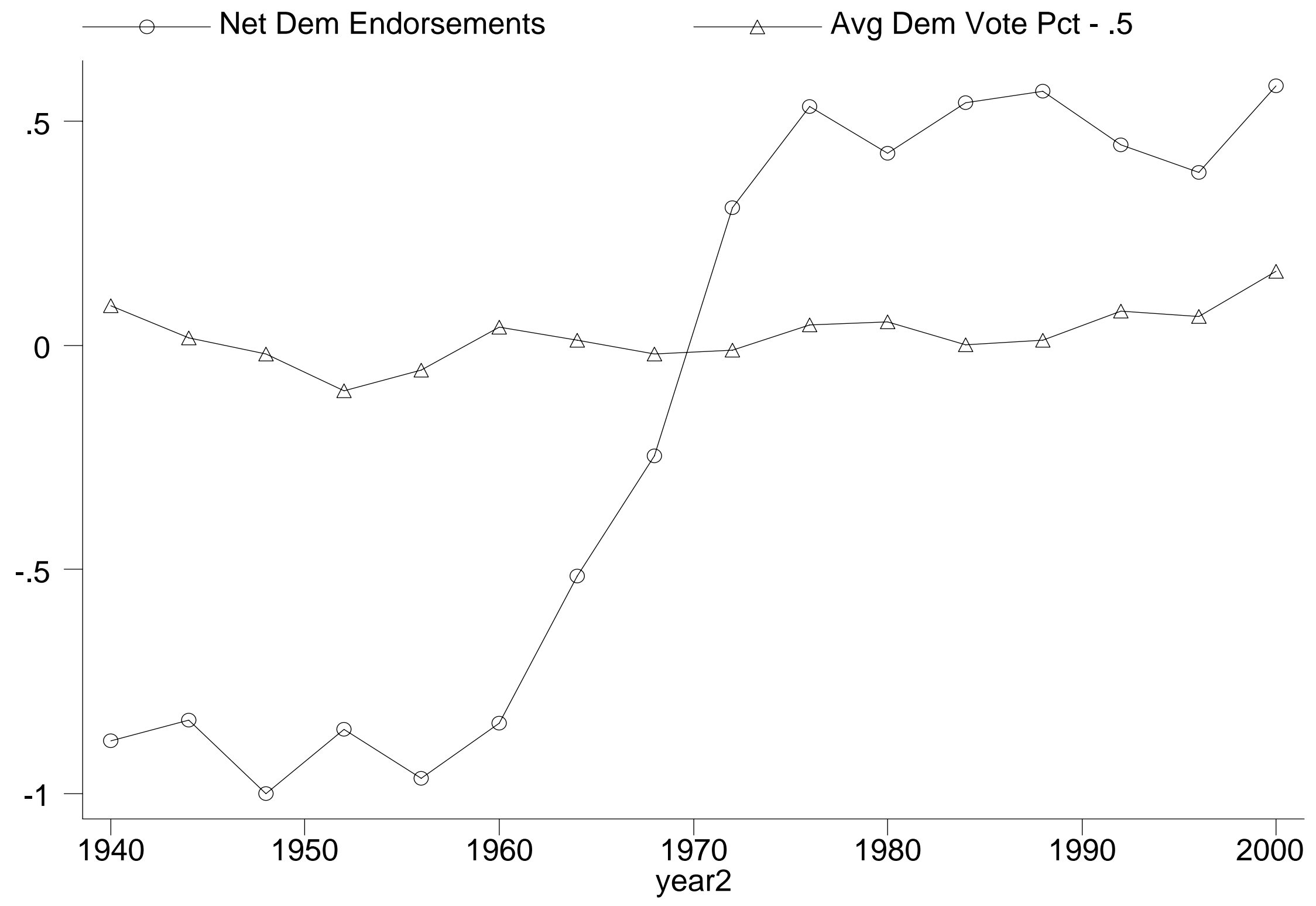


Figure 8: Coverage of unemployment and inflation on the LA Times.
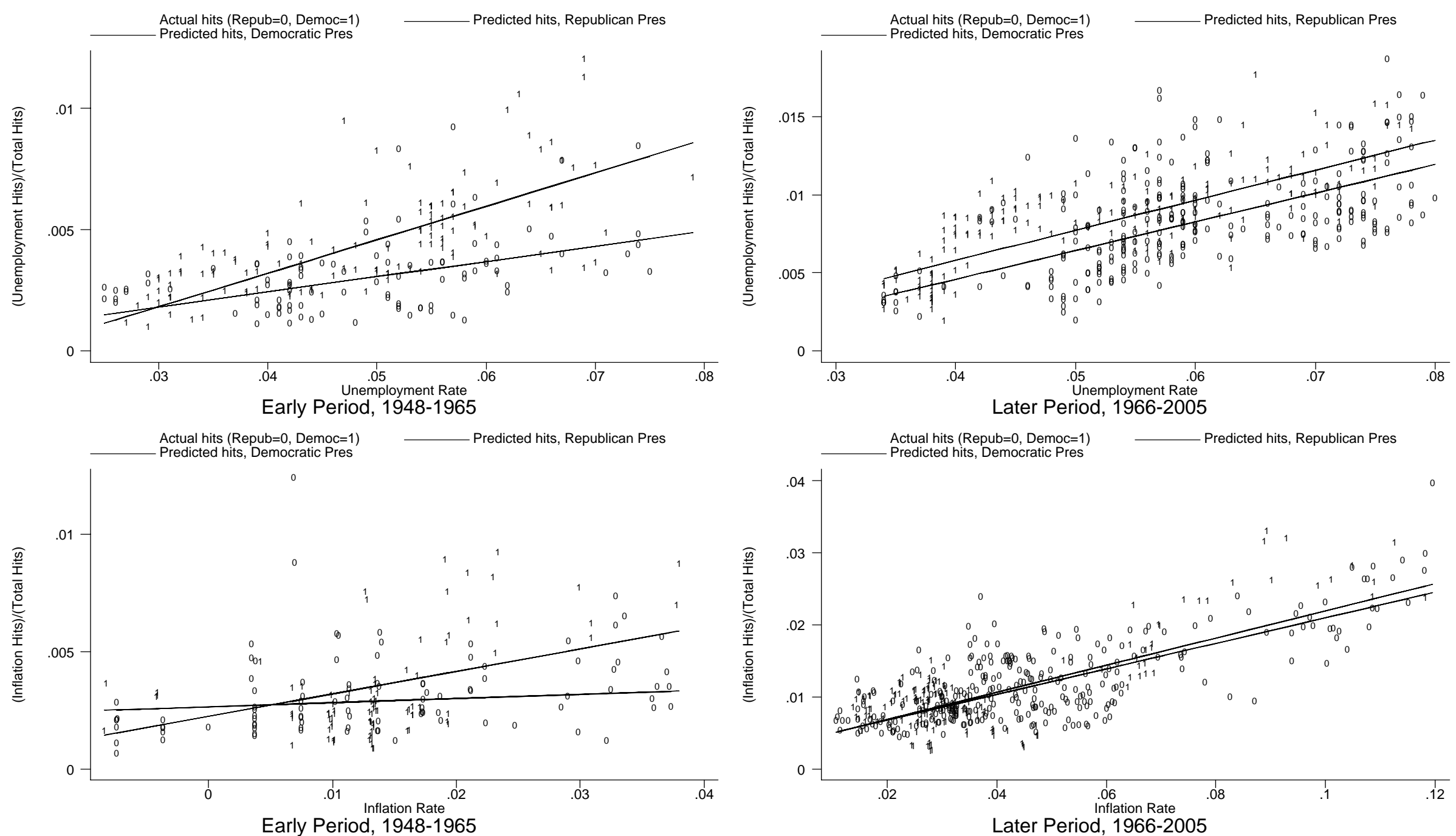

Los Angeles Times, Pre- and Post- Otis Chandler 
Table 1: variable definitions

\begin{tabular}{|l|l|l|l|}
\hline symbol & variable & definition & source \\
\hline$E V_{U t}$ & Unemployment & U.S. monthly unemployment rate & BLS, LNS 14000000 \\
\hline$E V_{I t}$ & Inflation & Monthly inflation rate, on annual basis & BLS, CPI data, CUUR0000SA0 \\
\hline$E V_{B t}$ & Budget deficit & Quarterly federal deficit, as percentage of GDP & BEA: NIPA Tables 3.2 and 1.1.5 \\
\hline$E V_{T t}$ & Trade deficit & Quarterly trade deficit, as percentage of GDP & BEA: NIPA Tables 4.1 and 1.1.5 \\
\hline$n_{j t}^{U}$ & Relative frequency of unemployment stories & Relative frequency of unemployment stories during month t on newspaper j & electronic search on www.NewsLibrary.com: (unemployment OR jobless) \\
\hline$n_{j t}^{I}$ & Relative frequency of inflation stories & Relative frequency of inflation stories during month t on newspaper j & electronic search on www.NewsLibrary.com: (inflation) \\
\hline$n_{j t}^{B}$ & Relative frequency of budget deficit stories & $\begin{array}{l}\text { Relative frequency of budget deficit/surplus stories during quarter t on } \\
\text { newspaper j }\end{array}$ & $\begin{array}{l}\text { electronic search on www.NewsLibrary.com: "government debt" OR } \\
\text { "government surplus" OR "government deficit" OR "federal debt" OR } \\
\text { "federal surplus" OR "federal deficit" }\end{array}$ \\
\hline$n_{j t}^{T}$ & Relative frequency of trade deficit stories & $\begin{array}{l}\text { Relative frequency of trade deficit/surplus stories during quarter t on } \\
\text { newspaper j }\end{array}$ & $\begin{array}{l}\text { electronic search on www.NewsLibrary.com: ("trade balance" OR "trade } \\
\text { deficit" OR "trade surplus") }\end{array}$ \\
\hline
\end{tabular}


Table 2: summary statistics, 1996-2005

\begin{tabular}{|c|c|c|c|c|c|c|c|}
\hline symbol & variable & Obs. & Mean & Median & Std. Dev. & Min & $\operatorname{Max}$ \\
\hline$\overline{E V_{U t}}$ & Monthly unemployment rate & 120 & 5.013 & 5.100 & 0.672 & 3.800 & 6.300 \\
\hline$E V_{B t}$ & Quarterly budget deficit & 40 & 1.047 & 1.229 & 1.936 & -2.209 & 4.114 \\
\hline$n{ }_{j t}^{U}$ & Relative frequency of unemployment stories & 12124 & 0.697 & 0.638 & 0.381 & 0 & 3.138 \\
\hline$n_{j t}^{I}$ & Relative frequency of inflation stories & 12124 & 0.572 & 0.478 & 0.402 & 0 & 3.824 \\
\hline$n{ }_{j t}^{B}$ & Relative frequency of budget deficit stories & 4049 & 0.127 & 0.102 & 0.106 & 0 & 1.887 \\
\hline
\end{tabular}

Notes: all economic figures and relative frequencies of stories are expressed in percentage points. 
Table 3: Partisan Bias in the Coverage of Economic Issues

\begin{tabular}{|c|c|c|c|c|c|c|c|c|c|c|c|c|}
\hline & \multicolumn{3}{|c|}{ unemployment } & \multicolumn{3}{|c|}{ inflation } & \multicolumn{3}{|c|}{ budget deficit } & \multicolumn{3}{|c|}{ trade deficit } \\
\hline & $(1)$ & $(2)$ & $(3)$ & $(4)$ & (5) & $(6)$ & $(7)$ & $(8)$ & $(9)$ & $(10)$ & (11) & $(12)$ \\
\hline Specification & $\mathrm{A}$ & $\mathrm{B}$ & $\mathrm{C}$ & $\mathrm{A}$ & $\mathrm{B}$ & $\mathrm{C}$ & $\mathrm{A}$ & $\mathrm{B}$ & $\mathrm{C}$ & $\mathrm{A}$ & $\mathrm{B}$ & $\mathrm{C}$ \\
\hline \multirow[t]{2}{*}{$\mathrm{DP} \times \mathrm{EV} \times \mathrm{NE}$} & -0.149 & -0.150 & -0.150 & 0.022 & 0.024 & 0.022 & -0.016 & -0.014 & -0.013 & 0.003 & 0.003 & 0.004 \\
\hline & $(2.38)^{\star \star}$ & $(2.38)^{\star \star}$ & $(2.35)^{\star \star}$ & $(0.82)$ & $(0.87)$ & $(0.81)$ & $(0.89)$ & $(0.76)$ & $(0.73)$ & $(0.29)$ & $(0.29)$ & $(0.30)$ \\
\hline \multirow[t]{2}{*}{ EV } & 0.165 & - & - & 0.084 & - & - & -0.012 & - & - & 0.001 & - & - \\
\hline & $(11.14)^{\star \star \star}$ & & & $(11.04)^{\star \star \star}$ & & & $(6.19)^{\star \star \star}$ & & & $(0.20)$ & & \\
\hline \multirow[t]{2}{*}{ Change in EV } & 0.094 & - & - & -0.020 & - & - & -0.002 & - & - & -0.005 & - & - \\
\hline & $(6.11)^{\star \star \star}$ & & & $(5.30)^{\star \star \star}$ & & & $(1.07)$ & & & $(1.87)^{\star}$ & & \\
\hline \multirow[t]{2}{*}{ DP } & 1.090 & - & - & 0.353 & - & - & 0.080 & - & - & 0.141 & - & - \\
\hline & $(9.33)^{\star \star \star}$ & & & $(9.99)^{\star \star \star}$ & & & $(10.55)^{\star \star \star}$ & & & $(12.08)^{\star \star \star}$ & & \\
\hline \multirow[t]{2}{*}{$\mathrm{DP} \times \mathrm{EV}$} & -0.248 & - & - & -0.073 & - & - & 0.029 & - & - & -0.027 & - & - \\
\hline & $(8.92)^{\star \star \star}$ & & & $(7.72)^{\star \star \star}$ & & & $(7.46)^{\star \star \star}$ & & & $(10.43)^{\star \star \star}$ & & \\
\hline \multirow[t]{2}{*}{$\mathrm{DP} \times \mathrm{NE}$} & 0.570 & 0.575 & - & -0.130 & -0.134 & - & -0.030 & -0.027 & - & -0.027 & -0.027 & - \\
\hline & $(2.15)^{\star \star}$ & $(2.15)^{\star \star}$ & & $(1.55)$ & $(1.60)$ & & $(0.91)$ & $(0.80)$ & & $(0.48)$ & $(0.48)$ & \\
\hline \multirow[t]{2}{*}{ NE $x$ EV } & 0.071 & 0.072 & - & -0.009 & -0.010 & - & 0.005 & 0.005 & - & 0.002 & 0.002 & - \\
\hline & $(1.99)^{\star \star}$ & $(2.02)^{\star \star}$ & & $(0.50)$ & $(0.55)$ & & $(1.04)$ & $(0.89)$ & & $(0.32)$ & $(0.35)$ & \\
\hline \multirow[t]{2}{*}{ In(total number of articles) } & 0.037 & 0.028 & 0.027 & 0.011 & 0.011 & 0.022 & -0.020 & -0.020 & -0.019 & 0.004 & 0.004 & 0.003 \\
\hline & $(1.88)^{\star}$ & $(1.40)$ & $(1.38)$ & $(0.79)$ & $(0.68)$ & $(1.30)$ & (1.11) & $(1.11)$ & $(0.90)$ & $(2.05)^{\star \star}$ & $(2.00)^{\star \star}$ & $(1.64)$ \\
\hline \multirow{5}{*}{$\begin{array}{l}\text { Newspaper fixed effects } \\
\text { Date dummies } \\
\text { Newspaper-specific time trend } \\
\text { Newspaper-specific slope w.r.t. EV } \\
\text { Newspaper-specific slope w.r.t. DP }\end{array}$} & yes & yes & yes & yes & yes & yes & yes & yes & yes & yes & yes & yes \\
\hline & no & yes & yes & no & yes & yes & no & yes & yes & no & yes & yes \\
\hline & yes & yes & yes & yes & yes & yes & yes & yes & yes & yes & yes & yes \\
\hline & no & no & yes & no & no & yes & no & no & yes & no & no & yes \\
\hline & no & no & yes & no & no & yes & no & no & yes & no & no & yes \\
\hline Observations & 12124 & 12124 & 12124 & 12124 & 12124 & 12124 & 4017 & 4017 & 4017 & 4021 & 4021 & 4021 \\
\hline R-squared & 0.56 & 0.63 & 0.67 & 0.66 & 0.72 & 0.75 & 0.39 & 0.61 & 0.66 & 0.66 & 0.70 & 0.74 \\
\hline
\end{tabular}

DP is a dummy equal to 1 when the president is a Democrat, EV stands for "Economic Variable", NE is the newspaper endorsement variable. Robust t statistics in parentheses. *

significant at $10 \%$; ${ }^{* *}$ significant at $5 \%$; ${ }^{* *}$ significant at $1 \%$ 
Table 4: Unemployment News, Robustness Checks

\begin{tabular}{|c|c|c|c|c|c|c|c|c|c|}
\hline & \multicolumn{3}{|c|}{ lagged values of the unemployment rate } & \multicolumn{3}{|c|}{ controlling for state-level unemployment } & \multicolumn{3}{|c|}{ excluding editorials } \\
\hline & $(1)$ & $(2)$ & (3) & $(4)$ & $(5)$ & $(6)$ & (7) & $(8)$ & (9) \\
\hline Specification & $\mathrm{A}$ & $\mathrm{B}$ & $\mathrm{C}$ & $\mathrm{A}$ & $\mathrm{B}$ & $\mathrm{C}$ & $\mathrm{A}$ & $\mathrm{B}$ & $\mathrm{C}$ \\
\hline DP $\times$ EV x NE (lagged) & $\begin{array}{l}-0.160 \\
(2.53)^{\star \star}\end{array}$ & $\begin{array}{c}-0.164 \\
(2.56)^{\star \star}\end{array}$ & $\begin{array}{c}-0.142 \\
(2.35)^{\star \star}\end{array}$ & - & - & - & - & - & - \\
\hline $\mathrm{DP} \times \mathrm{EV} \times \mathrm{NE}$ & - & - & - & $\begin{array}{c}-0.149 \\
(2.31)^{\star \star}\end{array}$ & $\begin{array}{c}-0.150 \\
(2.30)^{\star \star}\end{array}$ & $\begin{array}{c}-0.150 \\
(2.28)^{\star \star}\end{array}$ & $\begin{array}{c}-0.137 \\
(2.30)^{\star \star}\end{array}$ & $\begin{array}{c}-0.139 \\
(2.30)^{\star *}\end{array}$ & $\begin{array}{c}-0.138 \\
(2.26)^{\star *}\end{array}$ \\
\hline unemployment rate (lagged) & $\begin{array}{c}0.152 \\
(10.80)^{\star \star \star}\end{array}$ & - & - & - & - & - & - & - & - \\
\hline unemployment rate & - & - & - & $\begin{array}{c}0.111 \\
(6.08)^{\star \star \star}\end{array}$ & - & - & $\begin{array}{c}0.081 \\
(4.90)^{\star \star \star}\end{array}$ & - & - \\
\hline change in unemp. rate (lagged) & $\begin{array}{c}0.090 \\
(5.80)^{\star \star \star \star}\end{array}$ & - & - & - & - & - & - & - & - \\
\hline change in unemp. Rate & - & - & - & $\begin{array}{c}0.092 \\
(5.21)^{\star \star \star}\end{array}$ & - & - & $\begin{array}{c}0.088 \\
(5.23)^{\star \star \star}\end{array}$ & - & - \\
\hline DP & $\begin{array}{c}1.090 \\
(9.28)^{\star \star \star}\end{array}$ & - & - & $\begin{array}{c}1.081 \\
(9.36)^{\star \star \star}\end{array}$ & - & - & $\begin{array}{c}0.904 \\
(8.92)^{\star \star \star}\end{array}$ & - & - \\
\hline DP x unemployment (lagged) & $\begin{array}{c}-0.258 \\
(9.14)^{\star \star \star}\end{array}$ & - & - & - & - & - & - & - & - \\
\hline DP $x$ unemployment & - & - & - & $\begin{array}{c}-0.239 \\
(8.73)^{\star \star \star}\end{array}$ & - & - & $\begin{array}{c}-0.204 \\
(8.36)^{\star \star \star}\end{array}$ & - & - \\
\hline NE x unemployment (lagged) & $\begin{array}{c}0.072 \\
(2.14)^{\star \star}\end{array}$ & $\begin{array}{c}0.074 \\
(2.19)^{\star \star}\end{array}$ & - & - & - & - & - & - & - \\
\hline NE $x$ unemployment & - & - & - & $\begin{array}{c}0.070 \\
(1.95)^{\star}\end{array}$ & $\begin{array}{c}0.071 \\
(1.97)^{\star}\end{array}$ & - & $\begin{array}{c}0.053 \\
(1.88)^{\star}\end{array}$ & $\begin{array}{c}0.054 \\
(1.90)^{\star}\end{array}$ & - \\
\hline $\mathrm{DP} \times \mathrm{NE}$ & $\begin{array}{c}0.610 \\
(2.30)^{\star \star}\end{array}$ & $\begin{array}{c}0.623 \\
(2.34)^{\star \star}\end{array}$ & - & $\begin{array}{c}0.585 \\
(2.15)^{\star \star}\end{array}$ & $\begin{array}{c}0.588 \\
(2.14)^{\star \star}\end{array}$ & - & $\begin{array}{c}0.523 \\
(2.16)^{\star \star}\end{array}$ & $\begin{array}{c}0.529 \\
(2.16)^{\star \star}\end{array}$ & - \\
\hline In(total number of articles) & $\begin{array}{c}0.037 \\
(1.85)^{\star}\end{array}$ & $\begin{array}{l}0.027 \\
(1.36)\end{array}$ & $\begin{array}{l}0.027 \\
(1.35)\end{array}$ & $\begin{array}{c}0.041 \\
(2.20)^{\star \star}\end{array}$ & $\begin{array}{c}0.032 \\
(1.73)^{\star}\end{array}$ & $\begin{array}{l}0.030 \\
(1.58)\end{array}$ & $\begin{array}{c}0.038 \\
(2.37)^{\star \star}\end{array}$ & $\begin{array}{c}0.032 \\
(1.95)^{\star}\end{array}$ & $\begin{array}{c}0.030 \\
(1.72)^{\star}\end{array}$ \\
\hline state unemployment rate & - & - & - & $\begin{array}{c}0.061 \\
(3.37)^{\star \star \star}\end{array}$ & $\begin{array}{c}0.065 \\
(3.39)^{\star \star *}\end{array}$ & $\begin{array}{c}0.061 \\
(2.85)^{\star \star *}\end{array}$ & $\begin{array}{c}0.047 \\
(3.05)^{\star \star \star}\end{array}$ & $\begin{array}{c}0.051 \\
(3.17)^{\star \star \star}\end{array}$ & $\begin{array}{c}0.047 \\
(2.59)^{\star *}\end{array}$ \\
\hline change in state unemp. rate & - & - & - & $\begin{array}{c}0.054 \\
(3.24)^{\star \star \star}\end{array}$ & $\begin{array}{c}0.053 \\
(3.27)^{\star \star \star}\end{array}$ & $\begin{array}{c}0.054 \\
(3.58)^{\star \star \star}\end{array}$ & $\begin{array}{c}0.052 \\
(3.34)^{\star \star \star}\end{array}$ & $\begin{array}{c}0.050 \\
(3.21)^{\star \star \star}\end{array}$ & $\begin{array}{c}0.049 \\
(3.24)^{\star \star \star}\end{array}$ \\
\hline Newspaper fixed effects & yes & yes & yes & yes & yes & yes & yes & yes & yes \\
\hline Date dummies & no & yes & yes & no & yes & yes & no & yes & yes \\
\hline Newspaper-specific time trend & yes & yes & yes & yes & yes & yes & yes & yes & yes \\
\hline Newspaper-specific slope w.r.t. EV & no & no & yes & no & no & yes & no & no & yes \\
\hline Newspaper-specific slope w.r.t. DP & no & no & yes & no & no & yes & no & no & yes \\
\hline Editorials included & yes & yes & yes & yes & yes & yes & no & no & no \\
\hline Observations & 12116 & 12116 & 12116 & 12124 & 12124 & 12124 & 12106 & 12106 & 12106 \\
\hline R-squared & 0.56 & 0.63 & 0.67 & 0.56 & 0.64 & 0.67 & 0.58 & 0.64 & 0.67 \\
\hline
\end{tabular}

DP is a dummy equal to 1 when the president is a Democrat, EV stands for "Economic Variable", NE is the newspaper endorsement variable. Robust t statistics in

parentheses. * significant at $10 \%$; ${ }^{* *}$ significant at $5 \%$; *** significant at $1 \%$ 
Table 5: Unemployment News, different time windows, newspapers belonging to a chain or with large circulation

\begin{tabular}{|c|c|c|c|c|c|c|c|c|c|}
\hline & \multicolumn{3}{|c|}{$1988-2005$} & \multicolumn{3}{|c|}{$1992-2005$} & \multicolumn{3}{|c|}{$1996-2005$} \\
\hline & (1) & (2) & (3) & (4) & (5) & (6) & (7) & $(8)$ & (9) \\
\hline Specification & A & $\mathrm{B}$ & $\mathrm{C}$ & $A$ & $\mathrm{~B}$ & $\mathrm{C}$ & A & $\mathrm{B}$ & $\mathrm{C}$ \\
\hline$D P \times E V \times N E$ & $\begin{array}{l}-0.100 \\
(2.01)^{\star \star}\end{array}$ & $\begin{array}{l}-0.105 \\
(2.06)^{\star \star}\end{array}$ & $\begin{array}{l}-0.106 \\
(2.13)^{\star \star}\end{array}$ & $\begin{array}{l}-0.061 \\
(2.08)^{\star \star}\end{array}$ & $\begin{array}{l}-0.061 \\
(2.06)^{\star \star}\end{array}$ & $\begin{array}{l}-0.061 \\
(2.01)^{\star \star}\end{array}$ & $\begin{array}{l}-0.209 \\
(2.93)^{\star \star \star}\end{array}$ & $\begin{array}{c}-0.208 \\
(2.88)^{\star \star \star}\end{array}$ & $\begin{array}{c}-0.208 \\
(2.86)^{\star \star \star}\end{array}$ \\
\hline EV & $\begin{array}{c}0.194 \\
(7.82)^{\star \star \star}\end{array}$ & - & - & $\begin{array}{c}0.115 \\
(7.17)^{\star \star \star}\end{array}$ & - & - & $\begin{array}{c}0.098 \\
(4.70)^{\star \star \star}\end{array}$ & - & - \\
\hline Change in EV & $\begin{array}{c}0.086 \\
(4.00)^{\star \star \star}\end{array}$ & - & - & $\begin{array}{c}0.057 \\
(2.79)^{\star \star \star}\end{array}$ & - & - & $\begin{array}{c}0.091 \\
(5.04)^{\star \star \star}\end{array}$ & - & - \\
\hline DP & $\begin{array}{c}1.039 \\
(11.11)^{\star \star \star}\end{array}$ & - & - & $\begin{array}{c}0.624 \\
(11.50)^{\star \star \star}\end{array}$ & - & - & $\begin{array}{c}1.012 \\
(8.11)^{\star \star \star}\end{array}$ & - & - \\
\hline$D P \times E V$ & $\begin{array}{c}-0.176 \\
(12.16)^{\star \star \star}\end{array}$ & - & - & $\begin{array}{c}-0.126 \\
(14.03)^{\star \star \star}\end{array}$ & - & - & $\begin{array}{c}-0.224 \\
(7.58)^{\star \star \star}\end{array}$ & - & - \\
\hline $\mathrm{DP} \times \mathrm{NE}$ & $\begin{array}{l}0.526 \\
(1.68)\end{array}$ & $\begin{array}{c}0.548 \\
(1.71)^{\star}\end{array}$ & - & $\begin{array}{c}0.278 \\
(1.67)^{\star}\end{array}$ & $\begin{array}{l}0.279 \\
(1.65)\end{array}$ & - & $\begin{array}{l}0.790 \\
(2.60)^{\star \star}\end{array}$ & $\begin{array}{c}0.787 \\
(2.56)^{\star \star}\end{array}$ & - \\
\hline NE x EV & $\begin{array}{l}0.107 \\
(1.67)\end{array}$ & $\begin{array}{l}0.109 \\
(1.63)\end{array}$ & - & $\begin{array}{c}0.071 \\
(2.55)^{\star \star}\end{array}$ & $\begin{array}{l}0.072 \\
(2.52)^{\star \star}\end{array}$ & - & $\begin{array}{l}0.078 \\
(2.47)^{\star \star}\end{array}$ & $\begin{array}{c}0.079 \\
(2.48)^{\star \star}\end{array}$ & - \\
\hline In(total number of articles) & $\begin{array}{l}-0.154 \\
(2.56)^{\star \star}\end{array}$ & $\begin{array}{c}-0.194 \\
(3.17)^{\star \star \star}\end{array}$ & $\begin{array}{c}-0.139 \\
(2.77)^{\star \star \star}\end{array}$ & $\begin{array}{l}-0.006 \\
(0.11)\end{array}$ & $\begin{array}{l}-0.017 \\
(0.29)\end{array}$ & $\begin{array}{l}0.008 \\
(0.16)\end{array}$ & $\begin{array}{l}0.035 \\
(1.13)\end{array}$ & $\begin{array}{l}0.026 \\
(0.84)\end{array}$ & $\begin{array}{l}0.030 \\
(0.93)\end{array}$ \\
\hline state unemployment & $\begin{array}{c}0.090 \\
(5.10)^{\star \star \star}\end{array}$ & $\begin{array}{c}0.088 \\
(5.37)^{\star \star \star}\end{array}$ & $\begin{array}{c}0.082 \\
(4.30)^{\star \star \star}\end{array}$ & $\begin{array}{c}0.053 \\
(3.52)^{\star \star \star}\end{array}$ & $\begin{array}{c}0.055 \\
(3.60)^{\star \star \star}\end{array}$ & $\begin{array}{c}0.050 \\
(2.42)^{\star *}\end{array}$ & $\begin{array}{c}0.063 \\
(3.05)^{\star \star \star}\end{array}$ & $\begin{array}{c}0.067 \\
(3.11)^{\star \star \star}\end{array}$ & $\begin{array}{c}0.061 \\
(2.46)^{\star \star}\end{array}$ \\
\hline change in state unemployment & $\begin{array}{c}0.049 \\
(2.12)^{\star \star}\end{array}$ & $\begin{array}{l}-0.001 \\
(0.05)\end{array}$ & $\begin{array}{l}-0.012 \\
(0.51)\end{array}$ & $\begin{array}{c}0.074 \\
(4.31)^{\star \star \star}\end{array}$ & $\begin{array}{c}0.052 \\
(2.99)^{\star \star \star}\end{array}$ & $\begin{array}{c}0.039 \\
(2.20)^{\star *}\end{array}$ & $\begin{array}{c}0.061 \\
(3.52)^{\star \star \star}\end{array}$ & $\begin{array}{c}0.058 \\
(3.45)^{\star \star \star}\end{array}$ & $\begin{array}{c}0.059 \\
(3.61)^{\star \star \star}\end{array}$ \\
\hline $\begin{array}{l}\text { Newspaper fixed effects } \\
\text { Date dummies } \\
\text { Newspaper-specific time trend } \\
\text { Newspaper-specific slope w.r.t. EV } \\
\text { Newspaper-specific slope w.r.t. DP } \\
\text { Editorials included }\end{array}$ & $\begin{array}{c}\text { yes } \\
\text { no } \\
\text { yes } \\
\text { no } \\
\text { no } \\
\text { yes }\end{array}$ & $\begin{array}{l}\text { yes } \\
\text { yes } \\
\text { yes } \\
\text { no } \\
\text { no } \\
\text { yes }\end{array}$ & $\begin{array}{l}\text { yes } \\
\text { yes } \\
\text { yes } \\
\text { yes } \\
\text { yes } \\
\text { yes }\end{array}$ & $\begin{array}{c}\text { yes } \\
\text { no } \\
\text { yes } \\
\text { no } \\
\text { no } \\
\text { yes }\end{array}$ & $\begin{array}{c}\text { yes } \\
\text { yes } \\
\text { yes } \\
\text { no } \\
\text { no } \\
\text { yes }\end{array}$ & $\begin{array}{l}\text { yes } \\
\text { yes } \\
\text { yes } \\
\text { yes } \\
\text { yes } \\
\text { yes }\end{array}$ & $\begin{array}{c}\text { yes } \\
\text { no } \\
\text { yes } \\
\text { no } \\
\text { no } \\
\text { yes }\end{array}$ & $\begin{array}{c}\text { yes } \\
\text { yes } \\
\text { yes } \\
\text { no } \\
\text { no } \\
\text { yes }\end{array}$ & $\begin{array}{l}\text { yes } \\
\text { yes } \\
\text { yes } \\
\text { yes } \\
\text { yes } \\
\text { yes }\end{array}$ \\
\hline $\begin{array}{l}\text { Observations } \\
\text { R-squared } \\
\end{array}$ & $\begin{array}{l}8167 \\
0.60 \\
\end{array}$ & $\begin{array}{l}8167 \\
0.72 \\
\end{array}$ & $\begin{array}{l}8167 \\
0.77 \\
\end{array}$ & $\begin{array}{c}11856 \\
0.63 \\
\end{array}$ & $\begin{array}{c}11856 \\
0.71 \\
\end{array}$ & $\begin{array}{c}11856 \\
0.75 \\
\end{array}$ & $\begin{array}{c}10129 \\
0.55 \\
\end{array}$ & $\begin{array}{c}10129 \\
0.63 \\
\end{array}$ & $\begin{array}{c}10129 \\
0.66 \\
\end{array}$ \\
\hline
\end{tabular}

DP is a dummy equal to 1 when the president is a Democrat, EV stands for "Economic Variable", NE is the newspaper endorsement variable. Robust t statistics in parentheses. * significant at $10 \%$; ** significant at $5 \%$; ** significant at $1 \%$. 
Table 6: Unemployment News: Demand-driven coverage?

\begin{tabular}{|c|c|c|c|c|c|c|}
\hline & \multicolumn{3}{|c|}{ reader partisanship } & \multicolumn{3}{|c|}{ reader and endorsement partisanship } \\
\hline & (1) & (2) & (3) & (4) & $(5)$ & $(6)$ \\
\hline Specification & A & $\mathrm{B}$ & C & A & $\mathrm{B}$ & C \\
\hline $\mathrm{DP} \times \mathrm{EV} \times \mathrm{NR}$ & $\begin{array}{l}-0.648 \\
(1.78)^{\star}\end{array}$ & $\begin{array}{l}-0.663 \\
(1.82)^{\star}\end{array}$ & $\begin{array}{l}-0.644 \\
(1.73)^{*}\end{array}$ & $\begin{array}{l}-0.511 \\
(1.36)\end{array}$ & $\begin{array}{l}-0.526 \\
(1.40)\end{array}$ & $\begin{array}{l}-0.508 \\
(1.32)\end{array}$ \\
\hline $\mathrm{DP} \times \mathrm{EV} \times \mathrm{NE}$ & - & - & - & $\begin{array}{l}-0.128 \\
(1.98)^{\star}\end{array}$ & $\begin{array}{l}-0.129 \\
(1.96)^{*}\end{array}$ & $\begin{array}{l}-0.129 \\
(1.96)^{\star}\end{array}$ \\
\hline unemployment rate & $\begin{array}{l}-0.02 \\
(0.17)\end{array}$ & - & - & $\begin{array}{l}0.018 \\
(0.14)\end{array}$ & - & - \\
\hline change in unemp. rate & $\begin{array}{c}0.096 \\
(5.40)^{\star \star \star}\end{array}$ & - & - & $\begin{array}{c}0.094 \\
(5.31)^{\star \star \star}\end{array}$ & - & - \\
\hline DP & $\begin{array}{l}-0.036 \\
(0.05)\end{array}$ & - & - & $\begin{array}{l}0.258 \\
(0.32)\end{array}$ & - & - \\
\hline DP x unemployment & $\begin{array}{l}0.098 \\
(0.53)\end{array}$ & - & - & $\begin{array}{l}0.026 \\
(0.13)\end{array}$ & - & - \\
\hline NR $x$ unemployment & $\begin{array}{l}0.242 \\
(1.06)\end{array}$ & $\begin{array}{l}0.243 \\
(1.06)\end{array}$ & - & $\begin{array}{l}0.176 \\
(0.75)\end{array}$ & $\begin{array}{l}0.176 \\
(0.75)\end{array}$ & - \\
\hline$D P \times N R$ & $\begin{array}{l}2.141 \\
(1.43)\end{array}$ & $\begin{array}{l}2.193 \\
(1.46)\end{array}$ & - & $\begin{array}{l}1.586 \\
(1.01)\end{array}$ & $\begin{array}{l}1.638 \\
(1.04)\end{array}$ & - \\
\hline NE x unemployment & - & - & - & $\begin{array}{c}0.063 \\
(1.81)^{\star}\end{array}$ & $\begin{array}{l}0.064 \\
(1.83)^{\star}\end{array}$ & - \\
\hline $\mathrm{DP} \times \mathrm{NE}$ & - & - & - & $\begin{array}{c}0.521 \\
(1.88)^{\star}\end{array}$ & $\begin{array}{c}0.523 \\
(1.87)^{\star}\end{array}$ & - \\
\hline state unemployment rate & $\begin{array}{c}0.066 \\
(3.54)^{\star \star \star}\end{array}$ & $\begin{array}{c}0.07 \\
(3.56)^{\star \star \star}\end{array}$ & $\begin{array}{c}0.065 \\
(2.97)^{\star \star \star}\end{array}$ & $\begin{array}{c}0.064 \\
(3.49)^{\star \star \star}\end{array}$ & $\begin{array}{c}0.067 \\
(3.51)^{\star \star \star}\end{array}$ & $\begin{array}{c}0.064 \\
(2.94)^{\star \star \star}\end{array}$ \\
\hline change in state unemp. rate & $\begin{array}{c}0.048 \\
(2.78)^{\star \star \star}\end{array}$ & $\begin{array}{c}0.046 \\
(2.69)^{\star \star \star}\end{array}$ & $\begin{array}{c}0.049 \\
(3.10)^{\star \star \star}\end{array}$ & $\begin{array}{c}0.051 \\
(3.00)^{\star \star \star}\end{array}$ & $\begin{array}{c}0.050 \\
(2.96)^{\star \star \star}\end{array}$ & $\begin{array}{c}0.051 \\
(3.28)^{\star \star \star}\end{array}$ \\
\hline Newspaper fixed effects & yes & yes & yes & yes & yes & yes \\
\hline Date dummies & no & yes & yes & no & yes & yes \\
\hline Newspaper-specific time trend & yes & yes & yes & yes & yes & yes \\
\hline Newspaper-specific slope w.r.t. EV & no & no & yes & no & no & yes \\
\hline Newspaper-specific slope w.r.t. DP & no & no & yes & no & no & yes \\
\hline slope w.r.t. log of size & yes & yes & yes & yes & yes & yes \\
\hline Editorials included & yes & yes & yes & yes & yes & yes \\
\hline Observations & 12124 & 12124 & 12124 & 12124 & 12124 & 12124 \\
\hline R-squared & 0.56 & 0.64 & 0.67 & 0.56 & 0.64 & 0.67 \\
\hline
\end{tabular}

DP is a dummy equal to 1 when the president is Democratic, EV stands for "Economic Variable", NR is the newspaper readership variable, while NE is the newspaper endorsement one. Robust t statistics in parentheses. * significant at $10 \%$; ${ }^{*}$ significant at $5 \%$; ${ }^{* * *}$ significant at $1 \%$. 
Table A1: list of sampled newspapers with endorsement data

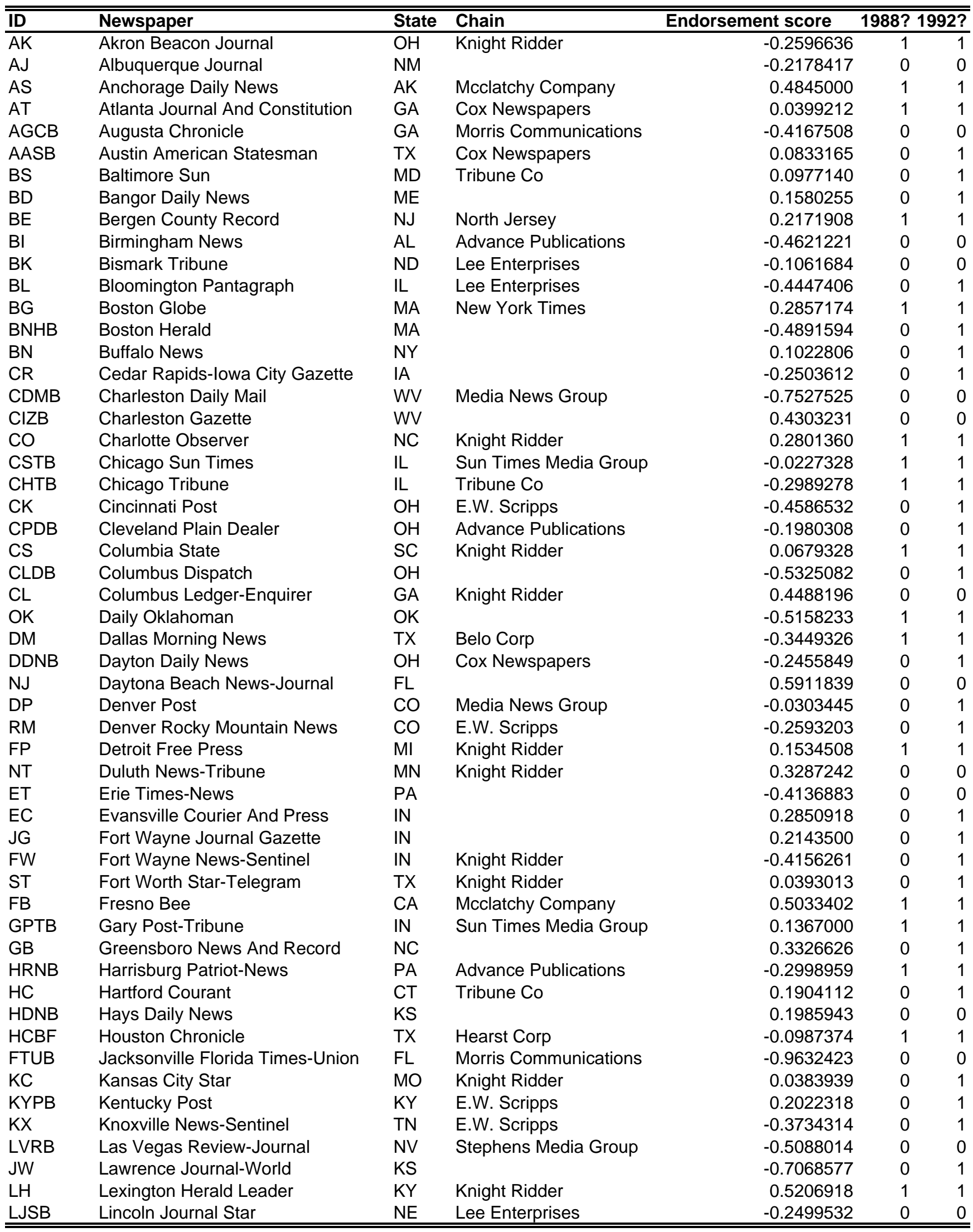

Notes: the last two columns specify whether data back to 1988 and to 1992 are available. 
Table A1 (cont.): list of sampled newspapers with endorsement data

\begin{tabular}{|c|c|c|c|c|c|c|}
\hline ID & Newspaper & State & Chain & Endorsement score & $1988 ?$ & 1992? \\
\hline LB & Long Beach Press-Telegram & CA & Media News Group & -0.2664053 & 0 & 1 \\
\hline NWDB & Long Island Newsday & NY & Tribune Co & 0.2436154 & 1 & 1 \\
\hline LA & Los Angeles Daily News & CA & Media News Group & -0.5388390 & 1 & 1 \\
\hline LAT & Los Angeles Times & CA & Tribune Co & 0.2779051 & 1 & 1 \\
\hline MT & Macon Telegraph & GA & Knight Ridder & 0.3271415 & 0 & 0 \\
\hline UL & Manchester Union Leader & $\mathrm{NH}$ & & -0.7585641 & 0 & 1 \\
\hline CA & Memphis Commercial Appeal & $\mathrm{TN}$ & E.W. Scripps & 0.1279533 & 0 & 1 \\
\hline $\mathrm{MH}$ & Miami Herald & $\mathrm{FL}$ & Knight Ridder & 0.2209475 & 1 & 1 \\
\hline MWSB & Milwaukee Journal Sentinel & WI & & 0.0230852 & 0 & 1 \\
\hline MN & Minneapolis Star Tribune & $\mathrm{MN}$ & & 0.2833712 & 1 & 1 \\
\hline MBRB & Mobile Register & AL & Advance Publications & -0.6182148 & 0 & 1 \\
\hline MS & Modesto Bee & CA & Mcclatchy Company & 0.0079176 & 0 & 1 \\
\hline NHRB & New Haven Register & CT & Journal Register Co & 0.0342288 & 1 & 1 \\
\hline TP & New Orleans Times-Picayune & LA & Advance Publications & 0.0230046 & 0 & 1 \\
\hline NYT & New York Times & NY & New York Times & 0.4166383 & 1 & 1 \\
\hline PBPB & Palm Beach Post & $\mathrm{FL}$ & Cox Newspapers & 0.3089388 & 0 & 1 \\
\hline JS & Peoria Journal Star & IL & Copley Press & -0.2456197 & 0 & 1 \\
\hline DN & Philadelphia Daily News & PA & Knight Ridder & 0.4773682 & 1 & 1 \\
\hline PI & Philadelphia Inquirer & PA & Knight Ridder & 0.1659037 & 1 & 1 \\
\hline PG & Pittsburgh Post Gazette & PA & Block Family & 0.0521412 & 0 & 1 \\
\hline OR & Portland Oregonian & OR & Advance Publications & 0.0527399 & 1 & 1 \\
\hline$A C$ & Press Of Atlantic City & NJ & & -0.2503979 & 1 & 1 \\
\hline RTDB & Richmond Times-Dispatch & VA & Media General & -0.7922730 & 1 & 1 \\
\hline RO & Roanoke Times & VA & Landmark Communication & 0.3516304 & 0 & 1 \\
\hline SB & Sacramento Bee & CA & Mcclatchy Company & 0.6049401 & 1 & 1 \\
\hline SAEC & San Antonio Express News & TX & Hearst Corp & -0.1073770 & 0 & 1 \\
\hline SFCB & San Francisco Chronicle & CA & & 0.2157588 & 1 & 1 \\
\hline SF & Santa Fe New Mexican & NM & & 0.0804830 & 0 & 0 \\
\hline SA & Santa Rosa Press Democrat & CA & New York Times & 0.3393954 & 0 & 0 \\
\hline HT & Sarasota Herald-Tribune & FL & New York Times & 0.0381942 & 0 & 0 \\
\hline IG & Seattle Post-Intelligencer & WA & Hearst Corp & 0.2872044 & 1 & 1 \\
\hline SE & Seattle Times & WA & & 0.0878302 & 1 & 1 \\
\hline $\mathrm{JR}$ & Springfield State Journal-Register & IL & Copley Press & -0.3135503 & 1 & 1 \\
\hline SL & St. Louis Post Dispatch & MO & Pulitzer Inc & 0.3241484 & 1 & 1 \\
\hline SP & St. Paul Pioneer Press & $\mathrm{MN}$ & Knight Ridder & -0.0365371 & 1 & 1 \\
\hline SPTB & St. Petersburg Times & FL & & 0.3125581 & 1 & 1 \\
\hline TNTB & Tacoma News Tribune & WA & Mcclatchy Company & 0.1453550 & 0 & 1 \\
\hline TD & Tallahassee Democrat & FL & Knight Ridder & 0.5688767 & 0 & 0 \\
\hline TT & Tampa Tribune & FL & Media General & -0.0522953 & 0 & 1 \\
\hline TB & Toledo Blade & $\mathrm{OH}$ & Block Family & 0.0791259 & 0 & 0 \\
\hline ADSB & Tucson Arizona Daily Star & AZ & Pulitzer Inc & 0.5186767 & 0 & 1 \\
\hline TLWB & Tulsa World & OK & & 0.1801442 & 0 & 1 \\
\hline VC & Vancouver Columbian & WA & & 0.1153056 & 0 & 0 \\
\hline WP & Washington Post & DC & & 0.1321356 & 1 & 1 \\
\hline WT & Washington Times & DC & & -1.1966380 & 0 & 1 \\
\hline WE & Wichita Eagle & KS & Knight Ridder & -0.3828387 & 1 & 1 \\
\hline WB & Wilkes-Barre Times Leader & PA & Knight Ridder & 0.8862112 & 0 & 1 \\
\hline WO & Worcester Telegram And Gazette & MA & New York Times & -0.5122839 & 0 & 1 \\
\hline
\end{tabular}

Notes: the last two columns specify whether data back to 1988 and to 1992 are available. 